\title{
\begin{tabular}{l|l} 
Mitraries & DSpace@MIT
\end{tabular}
}

\author{
MIT Open Access Articles
}

\section{Non-Diversifiable Volatility Risk and Risk Premiums at Earnings Announcements}

The MIT Faculty has made this article openly available. Please share how this access benefits you. Your story matters.

Citation: Barth, Mary E., and So, Eric C. “Non-Diversifiable Volatility Risk and Risk Premiums at Earnings Announcements." The Accounting Review 89, 5 (September 2014): 1579-1607

As Published: http://dx.doi.org/10.2308/accr-50758

Publisher: American Accounting Association

Persistent URL: http://hdl.handle.net/1721.1/111118

Version: Original manuscript: author's manuscript prior to formal peer review

Terms of use: Creative Commons Attribution-Noncommercial-Share Alike 


\title{
Non-Diversifiable Volatility Risk and Risk Premiums at Earnings Announcements
}

\author{
Mary E. Barth* \\ Stanford University \\ Graduate School of Business \\ Eric C. So \\ Massachusetts Institute of Technology \\ Sloan School of Management \\ January 2014
}

\begin{abstract}
This study seeks to determine whether earnings announcements pose non-diversifiable volatility risk that commands a risk premium. We find that investors anticipate some earnings announcements to convey news that increases market return volatility and pay a premium to hedge this non-diversifiable risk. In particular, we find evidence of risk premiums embedded in prices of firms' traded options that are significantly positively associated with the extent to which the firms' earnings announcements pose non-diversifiable volatility risk. In addition, we find that volatility risk premiums are concentrated among bellwether firms and result in predictable variation in option straddle returns around earnings announcements. Taken together, our findings show that some earnings announcements pose non-diversifiable volatility risk that commands a risk premium.
\end{abstract}

JEL: M41, G12, G13, G14

Keywords: Earnings announcements, non-diversifiable volatility risk, option pricing, risk premiums

\footnotetext{
*Corresponding author. Email addresses: mbarth@stanford.edu and eso@mit.edu. We appreciate the helpful comments from Leslie Hodder, Doron Israeli, Alan Jagolinzer, Travis Johnson, Charles Lee, Scott Richardson, Stephen Ryan, Terry Shevlin, Suhas Sridharan, Zach Wang, two anonymous reviewers, and Morton Pincus, editor, and workshop participants at Bocconi University; Harvard Business School; University of Houston; London Business School; Singapore Management University, especially discussant Sung Gon Chung; University of Wisconsin at Madison; American Accounting Association Annual Meeting; and Stanford Summer Camp, especially discussant Patricia Dechow.
} 


\section{Non-Diversifiable Volatility Risk and Risk Premiums at Earnings Announcements}

\section{INTRODUCTION}

A substantial literature in economics and finance provides evidence that the volatility of equity returns differs across securities and varies over time for a given security. Thus, investors in equity securities face at least two types of uncertainty. The first is uncertainty about how the security's price will change at any given time, which is captured by anticipated return volatility. This type of uncertainty is referred to as "price risk" and reflects investors' concern about adverse changes in the security's price. The second type is uncertainty about how the security's return volatility will change over time, which is captured by anticipated volatility in return volatility. This type of uncertainty is referred to as "volatility risk" and reflects investors' concern about increases in return volatility. Thus, price risk is associated with the first moment of the return distribution whereas volatility risk is associated with the second moment. Each type of risk can have a non-diversifiable component. Price risk is non-diversifiable to the extent that an asset's return covaries with the return of the market portfolio and volatility risk is nondiversifiable to the extent that an asset's return volatility covaries with the volatility of the market portfolio. The question we address is whether earnings announcements pose nondiversifiable volatility risk that commands a risk premium.

Asset pricing theory provides conceptual links for non-diversifiable price and volatility risks to affect an asset's expected return. Much of the classical asset pricing theory literature over the past 50 years focuses on price risk. The most common representation of price risk is the capital asset pricing model (CAPM) of Sharpe (1964) and Lintner (1965). In the CAPM, price risk is non-diversifiable when a security's return covaries with the market return. The CAPM predicts that a security's expected return is a linear function of its market beta because investors 
demand (pay) risk premiums for holding securities that lose (gain) value when the market portfolio declines. However, empirical tests of the CAPM largely fail to support its predictions and provide little evidence that equity returns are positively related to market betas. The empirical evidence does not establish that the CAPM's key pricing parameter-market beta -is associated with asset prices, and thus this literature fails to find that investors pay premiums to hedge non-diversifiable price risk.

Several decades after the development of the CAPM, innovations in option-pricing theory have given rise to models linking non-diversifiable volatility risk and expected option returns (Bates 2000; Pan 2002). These models predict that option prices reflect volatility risk premiums. Investors demand (pay) risk premiums for holding securities that lose (gain) value when market volatility increases because the increases reflect negative shocks to expected utility and consumption (Bansal, Khatchatrian, and Yaron 2005). Unlike equity securities, options provide a means to hedge increases in market volatility because option payoffs are higher when volatility is greater. To the extent that volatility reflects investor uncertainty, studying volatility risk allows researchers to measure the asset pricing implications of comovement in uncertainty about the values of a security and the market portfolio, which is distinct from studying price risk to measure the implications of comovement in the values of a security and the market portfolio.

The clear conceptual distinction between price risk and volatility risk motivated empirical tests of the latter, which yielded insights not obtainable from empirically testing the CAPM. For example, Pan (2002) shows empirically that non-diversifiable volatility risk affects index option prices. Similarly, Carr and $\mathrm{Wu}(2008)$ show that the volatility risk premium embedded in an option's price is proportional to the covariation of the underlying asset's return volatility with the market return volatility, i.e., non-diversifiable volatility risk, and is not explained by the 
covariance of returns, i.e., non-diversifiable price risk. Collectively, these studies find that investors pay premiums to hedge non-diversifiable volatility risk and document an empirical distinction between non-diversifiable volatility risk and non-diversifiable price risk.

Recognizing the potential for earnings news to convey information about the macroeconomy, prior research examines whether earnings announcements are a source of nondiversifiable risk. These studies focus on price risk and examine whether CAPM betas increase at earnings announcements. For example, Ball and Kothari (1991), Hsieh, Jerris, and Kross (1999), and Patton and Verardo (2012) provide evidence that CAPM betas increase at earnings announcements. Although this evidence indicates that non-diversifiable price risk increases at earnings announcements, these studies do not establish a link between the increase in betas and realized announcement returns. Ball and Kothari (1991) and Hsieh, Jerris, and Kross (1999) test for such a link but do not find one; Patton and Verardo (2012) do not test for such a link. Thus, similar to other tests of the CAPM, these studies do not provide evidence that investors pay premiums to hedge increases in non-diversifiable price risk at earnings announcements.

Our study differs from these studies by focusing on volatility risk as a separate and conceptually distinct type of risk posed by earnings announcements. Our findings indicate that earnings announcements can give rise to increases in market volatility, and thus are a source of non-diversifiable volatility risk. Based on the recent literature on volatility risk, we look to option prices for evidence of volatility risk premiums. Consistent with option-pricing theory, we find that prices of options with more exposure to non-diversifiable volatility risk at earnings announcements reflect larger risk premiums. This indicates that investors pay premiums to hedge non-diversifiable volatility risk associated with earnings announcements. Thus, our study is the 
first to show that earnings announcements are a source of non-diversifiable risk that has empirically verifiable implications for asset prices.

Following prior research, we base our proxy for volatility risk premiums at earnings announcements on excess implied volatility, i.e., announcement volatility implied by the firm's pre-announcement option prices in excess of realized announcement volatility. Excess implied volatility captures risk premiums because, when purchasing an option, an investor pays the option price to receive an asset that hedges increases in market volatility. The option hedges increases in volatility because higher volatility raises the likelihood that the option has a positive intrinsic value, i.e., is in-the-money, at expiration. The price the option writer receives includes compensation for bearing the corresponding increased risk of negative payoffs. When investors expect an increase in market volatility, the option writer cannot diversify risks of a particular option without purchasing additional securities at a cost, which reduces the writer's expected return. ${ }^{1}$ Thus, to the extent investors are averse to increases in market volatility, they pay risk premiums in the form of higher option prices to compensate option writers for bearing exposure to expected increases in market volatility. Because higher option prices correspond to higher implied volatility, excess implied volatility reveals the extent to which investors pay option prices that are higher than would be justified by realized volatility. Excess implied volatility corresponds to higher prices paid to the option writer but does not affect the payment the writer expects to incur to settle the option at expiration. Thus, excess implied volatility indicates a higher expected return to the writer and a lower expected return to the investor.

We measure the extent to which a firm's options hedge increases in market volatility at earnings announcements as the co-movement, i.e., contemporaneous changes in the same

\footnotetext{
${ }^{1}$ Option writers can hedge non-diversifiable volatility risk by simultaneously purchasing additional options. However, doing so does not eliminate the premium associated with bearing the risk of the written option; the cost of purchasing the hedging options equates to the risk premium.
} 
direction, of the firm's equity return volatility and the equity market return volatility at the firm's prior earnings announcements relative to non-announcement periods. Co-movement measures the tendency for the market and the firm's return volatilities to move together at the firm's earnings announcements, thereby capturing the extent to which the firm's earnings news reflects news about the market portfolio, and the extent to which the firm's options can serve as effective hedges of increases in market volatility at the announcements. ${ }^{2}$ As predicted, we find a significant positive relation between volatility risk premiums embedded in firms' preannouncement option prices and the extent to which the firm's earnings announcements pose non-diversifiable volatility risk. This result indicates that some earnings announcements pose non-diversifiable volatility risk that commands a risk premium.

Our inferences relating to non-diversifiable volatility risk are robust to controlling for firm size; whether the earnings announcement is good or bad news, the firm issues earnings guidance, the announcement is made before or after the market close, the announcement occurred prior to or after the recent financial crisis, or the announcement is made on a day when many other firms announce earnings; and using alternative approaches to determine the earnings announcement date and alternative measures of non-diversifiable volatility risk. In addition, we find that volatility risk premiums are concentrated among bellwether firms, i.e., firms that tend to convey more news about the macroeconomy (Anilowski, Feng, and Skinner 2007; Bonsall, Bozanic, and Fischer 2013). We find no evidence of a significant positive relation between nondiversifiable volatility risk and risk premiums for randomly assigned pseudo earnings announcement dates, which confirms that our inferences depend on earnings news.

\footnotetext{
${ }^{2}$ Investors can hedge non-diversifiable volatility risk by purchasing index options rather than individual firm options, and thus index option prices also reflect risk premiums. However, as discussed in Section III, using firm options rather than index options allows us to isolate the risk premium that is specific to earnings announcements.
} 
As an alternative measure of volatility risk premiums, we use returns to option straddle positions around earnings announcements. We find that high co-movement firms have straddle returns that are approximately $4 \%$ lower than low co-movement firms, which is a measure of the economic effect of non-diversifiable volatility risk on option prices around earnings announcements. This finding provides additional evidence that investors accept negative excess returns for holding options that hedge increases in market volatility at earnings announcements.

Finding that risk premiums emerge in anticipation of earnings news enhances our understanding of the information content of earnings announcements. In particular, we establish that earnings announcements pose non-diversifiable volatility risk that commands a risk premium. This result suggests that investors view earnings announcements as a source of uncertainty about market volatility and pay premiums to hedge this uncertainty.

The next section reviews related research and Section III develops the research design. Section IV describes the sample and presents descriptive statistics, Section V presents the main findings, and Section VI reports findings from additional analyses. Section VII concludes.

\section{RELATED LITERATURE}

\section{Earnings Announcements and Price Risk}

Prior research focusing on the equity market has looked for evidence that excess realized equity returns, a measure of risk premiums, at earnings announcements are positively related to changes in CAPM betas, a measure of non-diversifiable price risk. That price risk is time-varying is well-established (Epstein and Turnbull 1980) and earnings announcements can convey news about the value of the market portfolio. However, although prior research finds evidence of positive excess realized equity returns at earnings announcements and increases in CAPM betas, it fails to establish a significant positive relation between them. 
Ball and Kothari (1991) find that excess returns increase at earnings announcements, with CAPM betas significantly higher only on the day before and the day after the earnings announcement, but not on the day of the announcement, and only for smaller firms. However, Ball and Kothari (1991) find that the changes in betas are not significantly positively associated with the excess returns, and conclude that price risk associated with earnings news is primarily diversifiable. Hsieh, Jerris, and Kross (1999) also find increases in CAPM betas and positive excess returns at earnings announcements, but find that excess announcement returns do not differ significantly across portfolios formed based on the increase in betas. Patton and Verardo (2012) use intraday data to estimate daily firm-level CAPM betas and find strong evidence of increases in betas at earnings announcements for S\&P500 firms, but do not test whether the increases are associated with excess returns. The absence of a significant link between CAPM betas and realized returns is not limited to earnings announcements. The theoretical link between non-diversifiable price risk, as measured by CAPM betas, and equity returns has been rejected empirically in a variety of contexts, as reviewed by Fama and French (2004). ${ }^{3}$

Cohen, Dey, Lys, and Sunder (2007) revisit the existence of positive excess announcement returns, in part because of the many changes in institutions and markets since the early 1990s. Cohen et al. (2007) find such returns, although the returns are smaller than those reported in Ball and Kothari (1991). They interpret this finding, together with finding higher realized equity volatility at earnings announcements than reported in Ball and Kothari (1991), as consistent with changes in the amount and cost of arbitrage. That is, Cohen et al. (2007) interpret

\footnotetext{
${ }^{3}$ For example, prior research also fails to find a significant positive relation between increases in CAPM betas and excess returns at quarterly dividend announcements. Kalay and Lowenstein (1985) find positive excess returns and a significant increase in beta, but the increase in beta does not explain the return. Eades, Hess, and Kim (1985) find positive excess returns, but no evidence of an increase in betas.
} 
the positive excess announcement returns as evidence of mispricing that is too costly to arbitrage away, rather than as compensation for bearing non-diversifiable price risk. ${ }^{4}$

\section{Equity Volatility, Earnings Announcements, and Option Prices}

A vast literature documents large, rapid equity price reactions to earnings announcements, which suggest that equity volatility increases in response to earnings news (Ball and Brown 1968; Beaver 1968; Patell and Wolfson 1984), and documents higher equity return volatility around earnings announcements (Beaver 1968; Patell and Wolfson 1981). ${ }^{5}$

Patell and Wolfson $(1979 ; 1981)$ use the insight from Merton (1973) that expected equity return volatility in the Black and Scholes (1974) option-pricing formula can be expressed as the weighted average of the firm's baseline volatility and increases in its volatility associated with an anticipated information event. Patell and Wolfson $(1979 ; 1981)$ show that option traders anticipate increases in firms' equity return volatility at earnings announcements and that the level of anticipated volatility is reflected in pre-announcement option prices. Dubinsky and Johannes (2006) find that incorporating increases in firms' equity return volatility associated with information events into the option-pricing model significantly reduces option-pricing errors, and that uncertainty about return volatility at earnings announcements plays a central role in determining option prices for a sample of 20 firms from 1996 to 2002 . We follow this literature by viewing earnings announcements as a source of increased equity volatility that is reflected in option prices prior to the announcement. We also follow this literature in estimating implied

\footnotetext{
${ }^{4}$ Some studies find evidence of intra-industry information transfers at earnings announcements (Foster 1981; Olsen and Dietrich 1985; Baginski 1987; Han, Wild, and Ramesh 1989). However, because the firms affected by such transfers are, by definition, a subset of the market, one would not expect the transfers to pose non-diversifiable risk. ${ }^{5} \mathrm{Kim}$ and Verrecchia (1994) model variation in investors' interpretation of earnings news, which can increase the asymmetric information component of bid-ask spreads at earnings announcements. This increase in spreads can mechanically increase equity volatility because of the bid-ask bounce. We have no reason for why option prices would fail to reflect these increases in volatility, and thus have no reason for why they would bias our findings in favor of our predictions.
} 
volatility for the earnings announcement day by expressing expected equity volatility as a combination of baseline volatility and an increase in volatility associated with the announcement.

\section{Volatility Risk and Risk Premiums Embedded in Option Prices}

Prior research provides evidence that the volatility of returns is time varying (Bollerslev, Engle, and Nelson 1994; Anderson, Bollerslev, and Diebold 2005). Uncertainty about how volatility will change creates volatility risk. When volatility risk is non-diversifiable, such as when earnings news affects the volatilities of the announcing firm's equity and the market portfolio, we expect option writers will command a premium for bearing it.

Based on the Merton (1973) insight that realized and option-implied equity volatilities

should be equal on average in the absence of additional priced risk, prior research establishes that option prices reflect premiums associated with non-diversifiable volatility risk. Jackwerth and Rubinstein (1996) and Pan (2002) find that equity volatility implied by prices of S\&P500 index options is higher than subsequently realized index volatility, and Pan (2002) shows that premiums associated with non-diversifiable volatility risk can explain the difference. In particular, Pan (2002) develops a model that allows for shocks to equity volatility and estimates the joint time series of S\&P500 index option-implied and realized volatilities, and finds that market volatility risk results in implied volatility that is systematically larger than realized volatility. Pan (2002) interprets this finding as indicating that option traders demand a premium for holding the index options over a period that exposes them to non-diversifiable volatility risk. Bansal and Yaron (2004), Bansal, Khatchatrian, and Yaron (2005), Lustig and Van Nieuwerburgh (2008), and Bansal, Kiku, Shaliastovich, and Yaron (2012) explain why investors pay premiums to hedge against increases in market volatility. These studies explain that market volatility carries a risk premium because market volatility measures shocks to economic growth 
and aggregate utility, and Bansal et al. (2012) show that high market volatility coincides with increased investment risk and significant declines in expected consumption. This explanation is consistent with the well-documented negative relation between market volatility and contemporaneous index returns (Bollerslev, Tauchen, and Zhou 2009).

Broadie, Chernov, and Johannes (2007) detect sharp increases in realized volatility for S\&P500 index options and provide evidence of risk premiums embedded in option prices by comparing implied and realized volatilities. ${ }^{6}$ Todorov (2009) examines temporal variation in volatility risk premiums using high-frequency data on the S\&P500 index and variance swap rates, and finds that premiums reflected as differences between realized volatility and volatility implied by the swap rates increase following shocks to market volatility. Carr and Wu (2008) estimate volatility risk premiums for five stock indexes and 35 firms by comparing realized volatilities and volatility implied from synthetic variance swap rates. Collectively, these studies establish that market volatility risk plays a role in determining option prices. We follow this literature by basing our proxy for volatility risk premiums on the difference between equity volatility implied by option prices and realized equity volatility. Using prices of a firm's traded options rather than index options to estimate implied volatility gives us a risk premium measure for each firm-quarter and enables us to make a direct link between the risk premiums and the firm's earnings announcements.

\section{Non-diversifiable Earnings News}

Earnings news can pose non-diversifiable risk to the extent the news pertains to the market portfolio. Consistent with this possibility, Ball, Sadka, and Sadka (2009) use factor

\footnotetext{
${ }^{6}$ The option-pricing literature also documents that highly out-of-the-money (OTM) options yield highly negative returns (Jackwerth 2000; Borarenko 2003). Broadie, Chernov, and Johannes (BCJ 2007; 2009) find that observed returns to OTM written options are consistent with expectations of jumps in equity prices. The BCJ findings suggest that the negative returns for OTM options are attributable to investors using the options to hedge future price jumps.
} 
analysis to extract a market-wide component of earnings, and conclude that because earnings are positively correlated across firms, risk associated with changes in earnings is unlikely to be fully diversifiable. A firm's earnings news can help investors form expectations about future marketwide cash flows, where positive (negative) earnings news is associated with increases (decreases) in expected cash flows, and thus with positive (negative) market returns. Anilowski, Feng, and Skinner (2007) focus on management earnings guidance rather than earnings announcements, and find that negative market returns are associated with downward earnings guidance by large firms. Related evidence in Bonsall, Bozanic, and Fischer (2013) demonstrates that firms' earnings guidance can provide investors timely information about the macroeconomy. A firm's earnings news also can help investors form expectations about market discount rates, where positive (negative) earnings news is associated with increases (decreases) in the expected discount rate, and thus with negative (positive) market returns. Kothari, Lewellen, and Warner (2006) document a negative relation between quarterly equity market index returns and quarterly unexpected aggregate earnings, and infer that unexpected earnings influences market discount rates. Supporting this inference, Cready and Gurun $(2009 ; 2010)$ find that on earnings announcement days, daily aggregate earnings is negatively related to daily market index returns incremental to past daily aggregate earnings, and positively related to Treasury bond rates and expected inflation. We follow this literature by viewing earnings announcements as a potential source of market-wide information that can be positively or negatively associated with the sign of the earnings news, and thus associated with non-diversifiable volatility risk.

Collectively, our findings contribute to the literature on the information content of earnings news by providing evidence that some earnings announcements are associated with increases in non-diversifiable volatility risk and that investors pay a premium in the form of 
higher option prices to hedge this risk. Our study is the first to establish that some earnings announcements pose non-diversifiable volatility risk that commands a risk premium.

\section{RESEARCH DESIGN}

We first construct a proxy for volatility risk premiums embedded in pre-earnings announcement prices of a firm's options, and then test whether our proxy is significantly positively related to our measure of announcement-specific non-diversifiable volatility risk.

\section{Risk Premium Proxy}

Following Pan (2002), Broadie, Chernov, and Johannes (2007), Todorov (2009), and Carr and $\mathrm{Wu}(2008)$ but modified to our setting, we use implied earnings announcement volatility in excess of realized earnings announcement volatility, ExVOL, as our proxy for volatility risk premiums:

$$
\operatorname{ExVOL}_{q} \equiv 1-\operatorname{sdev}\left(\frac{R E T_{q}}{I A V_{q}}\right),
$$

where $R E T_{q}$ is the firm's one-day quarter $q$ realized earnings announcement return, $I A V_{q}$ is implied announcement volatility, i.e., the standard deviation of the firm's one-day quarter $q$ earnings announcement return implied by pre-announcement prices of the firm's traded options, and sdev denotes standard deviation. ${ }^{7}$

Appendix A explains how we estimate $I A V_{q}$. In brief, we model implied volatility as the sum of baseline volatility and the anticipated increase in volatility at the earnings announcement, averaged over the remaining life of the option (Merton 1973; Patell and Wolfson 1979; 1981). This leads to the following expression for implied announcement volatility:

\footnotetext{
${ }^{7}$ Even though we express $I A V$ as a standard deviation, we refer to it as implied announcement volatility because we measure it using volatility implied by option prices.
} 


$$
I A V_{q}=\sqrt{\sigma_{E A}^{2}+\sigma^{2} / 252}
$$

where $\sigma_{E A}^{2}$ is the one-day increase in implied volatility at the earnings announcement, $\sigma^{2}$ is implied baseline volatility expressed in annualized units, and 252 is the number of trading days in a year. Because both implied volatilities in equation (2), $\sigma_{E A}^{2}$ and $\sigma^{2}$, are unknown, estimating them requires using two pre-announcement option prices; we use prices of the firm's 30 - and 60day standardized at-the-money call options. To reduce measurement error in calculating $I A V_{q}$, we use the five-day averages of $\sigma_{E A}^{2}$ and $\sigma^{2}$ implied by option prices on days $t-6$ to $t-2$, where day $t$ is the earnings announcement date.

In equation (1), $R E T_{q} / I A V_{q}$ is the firm's quarter $q$ earnings announcement return scaled by its implied standard deviation. Under the null hypothesis that implied volatility equals realized volatility, $R E T_{q} / I A V_{q}$ has a standard normal distribution, and thus $\operatorname{sdev}\left(R E T_{q} / I A V_{q}\right)$ equals one. ${ }^{8}$ We calculate $\operatorname{sdev}\left(R E T_{q} / I A V_{q}\right)$ over quarters $q$ to $q+9$ because each earnings announcement yields only one observation from the return distribution; using ten future announcements gives us ten observations of returns realized after the quarter $q$ earnings announcement. Under the null hypothesis, each observation of $R E T_{q} / I A V_{q}$ is drawn from the standard normal distribution. As a result, expressing ExVOL as in equation (1) means that if implied volatility equals realized

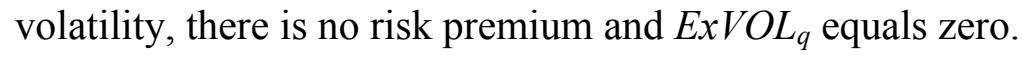

Our tests focus on the alternative hypothesis that there is a volatility risk premium to the extent that the increase in volatility at the earnings announcement is non-diversifiable. In such circumstances, we expect implied volatility to exceed realized volatility, so that $\operatorname{sdev}\left(R E T_{q} / I A V_{q}\right)$ is less than one, which indicates that writers of options written before, but maturing after, the

\footnotetext{
${ }^{8}$ The numerator of ExVOL is signed, not absolute, returns because $I A V$ is the implied standard deviation of signed returns under the null hypothesis of no risk premiums.
} 
announcements charge more for the options than would be justified by realized volatility. We define $E x V O L_{q}$ as $1-\operatorname{sdev}\left(R E T_{q} / I A V_{q}\right)$ so that $E x V O L_{q}$ is increasing in the risk premium.

We use option prices to construct our volatility risk premium proxy because, as explained in Section II, there is theory linking non-diversifiable volatility risk and option prices. The volatility of equity returns is a key determinant of option prices through the option's time value. Thus, non-diversifiable risk associated with volatility should affect option prices. We are unaware of any theory linking non-diversifiable volatility risk and equity prices.

Using option price-based risk premiums has several other advantages over using realized equity returns, which may explain why we find a significant positive relation between increases in non-diversifiable risk at earnings announcements and risk premiums and prior research using realized equity returns does not. First, the theoretical link between non-diversifiable volatility risk and excess implied volatility is well-supported in empirical tests, whereas the theoretical link between non-diversifiable price risk, as measured by CAPM betas, and equity returns has been largely rejected (Fama and French 2004). Second, using realized returns to infer risk premiums is confounded by the realization of unanticipated cash flows, revisions in market expectations of future cash flows, and changes in discount rates (Elton 1999). These concerns are amplified at earnings announcements because earnings reflect information about the firm's past and future cash flows, which increases the difficulty of isolating the component of returns related to risk.

Third, as Section II explains, prior research establishes that equity volatility changes in a predictable pattern around earnings announcements. Using pre-announcement option prices enables us to obtain an ex ante measure of volatility risk because expected equity volatility is a key input in determining option prices. Using pre-announcement option prices allows us to compare expected and realized announcement volatility, thereby permitting us to assess the 
extent to which the option prices reflect risk premiums directly associated with earnings news. Finally, because option markets attract sophisticated and privately informed investors, option prices are more likely to be informationally efficient than equity prices (Black 1975; Easley, O’Hara, and Srinivas 1998; Pan and Poteshman 2006; Johnson and So 2012). This suggests mispricing is less likely to confound option price-based estimates of risk and risk premiums.

\section{Risk Premiums and Non-Diversifiable Volatility Risk at Earnings Announcements}

To test whether non-diversifiable volatility risk at earnings announcements is positively associated with risk premiums, we estimate equation (3):

$$
\begin{aligned}
\text { ExVOL }_{q}= & \alpha_{0}+\alpha_{1} \text { COMOVE }_{q}+\alpha_{2} \text { ANBETA }_{q}+\alpha_{3} \text { SAMEDATE }_{q} \\
& +\alpha_{4} \mid \text { RET }_{q}\left|+\alpha_{5}\right| \text { HISTRET }_{q} \mid+\alpha_{6} \operatorname{SIZE}_{q}+\varepsilon_{q} .
\end{aligned}
$$

The focus of our tests is $\alpha_{1}$, the coefficient on COMOVE. We design COMOVE to measure the tendency for the market and the firm's return volatilities to move together at the firm's earnings announcements, thereby capturing the extent to which the firm's earnings news reflects news about the market portfolio. Thus, COMOVE reflects the extent to which the firm's options can serve as hedges of volatility risk at the announcements.

Specifically, COMOVE is the difference between the absolute difference between the firm's absolute equity return, $\left|R E T_{t}\right|$, and the absolute equal-weighted market return, $\left|M K T_{t}\right|$, on earnings announcement days and non-announcement days. ${ }^{9}$

$$
\mathrm{COMOVE}_{q}=-1 \times\left\{\left.|| R E T_{t}|-| M K T_{t}\right|_{E A}-\|\left. R E T_{t}|-| M K T_{t}\right|_{N E A}\right\},
$$

where $E A(N E A)$ denotes the average co-movement on earnings announcement (nonannouncement) days for the 12 quarters prior to quarter $q$. We multiply the difference in co-

\footnotetext{
${ }^{9}$ Our inferences, i.e., whether the coefficients on COMOVE, ANBETA, and SAMEDATE are significantly positive, are unaffected if we use the value-weighted market return or the return on the S\&P500 index.
} 
movement on earnings announcement days and non-announcement days by negative one so that higher $\mathrm{COMOVE}_{q}$ corresponds to greater non-diversifiable volatility risk. We measure $\mathrm{COMOVE}_{q}$ in the 12 quarters prior to quarter $q$ to enable us to test whether past evidence of nondiversifiable volatility risk at a firm's earnings announcements results in risk premiums associated with future earnings announcements. We expect that the extent of co-movement is positively related to volatility risk premiums embedded in the announcing firm's option prices because option writers demand compensation for bearing exposure to non-diversifiable volatility risk. Thus, we predict $\alpha_{1}$ is positive.

Although ExVOL is designed to capture risk premiums associated with non-diversifiable volatility risk, it also could reflect premiums associated with other types of non-diversifiable risk. ${ }^{10}$ In particular, option prices are affected by non-diversifiable equity price risk because the option's intrinsic value depends on equity prices. For this reason, and to distinguish nondiversifiable volatility and price risks, we include $A N B E T A$ in equation (3), which represents the change in the firm's CAPM beta at earnings announcements. Specifically, $A N B E T A_{q}$ is $\beta_{3}$ from the following firm-specific regression, which we estimate over the 12 quarters prior to quarter $q$ (Heish, Jerris, and Kross 1999):

$$
\operatorname{RET}_{t}=\beta_{0}+\beta_{1} M K T_{t}+\beta_{2} \text { AnnDate }_{t}+\beta_{3} M K T_{t}^{*} \text { AnnDate }_{t}+\varepsilon_{t} .
$$

\footnotetext{
${ }^{10}$ Differences between implied and realized volatility also could reflect option mispricing. However, we estimate two implied volatility parameters, which mitigates concerns about our implied volatility measure reflecting option pricing model misspecification. In particular, $\sigma_{E A}^{2}$ captures the change in implied volatility at earnings announcements, not the level of implied volatility for the firm's options, $\sigma^{2}$. Thus, any model misspecification likely affects $\sigma^{2}$ more than $\sigma_{E A}^{2}$, which is the major portion of implied announcement volatility, $I A V$. Also, Goyal and Sarreto (2009) find that differences between implied and historical volatilities predict future option returns, which can represent risk premiums or model misspecification. However, implied volatility is expected future, not historical, volatility. In contrast, our risk premium proxy is based on differences between implied and realized volatilities for the same time period. Merton's (1973) insight that implied and realized volatilities for the same time period should be equal does not apply to differences between implied and historical volatilities. Regardless, we have no reason to believe that any option mispricing would bias in favor of our finding a significant positive relation between ExVOL and COMOVE.
} 
AnnDate $_{t}$ is an indicator variable that equals one on days within the three-day quarterly earnings announcement window, i.e., days $t-1, t$, and $t+1$ relative to earnings announcement day $t$. Because $\beta_{1}$ is the firm's CAPM beta during non-announcement periods, $\beta_{3}$ is the change in beta at earnings announcements. To the extent that increases in beta reflect greater non-diversifiable risk of writing options through the options' intrinsic values, we expect market makers to demand compensation in the form of higher option prices. Thus, we predict that $\alpha_{2}$ in equation (3) is positive reflecting a positive relation between $E x V O L$ and non-diversifiable price risk.

We also include in equation (3) a generic measure of non-diversifiable risk, SAMEDATE $_{q}$, which is the natural logarithm of the number of firms in Compustat that in quarter $q$ had the same earnings announcement date as the firm. ${ }^{11}$ We interpret SAMEDATE as a nonmarket-based measure of aggregate earnings news conveyed on the firm's earnings announcement day. In this interpretation, higher values correspond to greater non-diversifiable risk because the more firms that announce earnings on the same day, the more likely it is that investors expect the news on that day to be market-wide. Thus, we predict $\alpha_{3}$ is positive. However, SAMEDATE also could be a measure of investor inattention (Hirshleifer, Lim, and Teoh 2009), which would weaken the market reaction to the firm's earnings news. Thus, to the extent SAMEDATE measures investor inattention, its relation with ExVOL will be attenuated. For this reason, we do not expect SAMEDATE to have as strong a relation with ExVOL as COMOVE. We also include three control variables in equation (3). $\left|R E T_{q}\right|$ is the firm's absolute quarter $q$ one-day announcement return and $\left|H I S T R E T_{q}\right|$ is $\left|R E T_{t}-M K T_{t}\right|_{E A}$, which is the average

\footnotetext{
${ }^{11}$ We base $S A M E D A T E$ on quarter $q$ earnings announcements because we assume investors have rational, updated expectations regarding quarter $q$ earning announcements and, unlike COMOVE and ANBETA, SAMEDATE does not depend on announcement returns, which we use to construct ExVOL. Regardless, untabulated findings reveal that inferences based on estimating equation (3) using lagged SAMEDATE are largely the same as those based on Table 3. The only difference is that the coefficient on lagged $S A M E D A T E$ is significantly positive in columns (3) through (6), whereas the coefficient on SAMEDATE is positive in all four columns, but only significantly so in column (6).
} 
over the 12 quarters prior to quarter $q$ of the absolute difference between $R E T_{t}$ and $M K T_{t}$ on each earnings announcement date. $\left|R E T_{q}\right|$ and $\left|H I S T R E T_{q}\right|$ are both based on the returns we use to construct COMOVE, but are not directly related to the extent to which the volatilities of a firm's return and the market return comove. Thus, we view these variables as controls for any mechanical relation between COMOVE and ExVOL related to using returns to construct both variables. We do not predict the signs of $\alpha_{4}$ and $\alpha_{5} . S I Z E_{q}$ is the natural logarithm of firm's market value of equity at the end of quarter $q-1$. Although unconditionally we expect earnings announcements of larger firms are more likely to convey market-wide news than those of smaller firms, we do not predict the sign of $\alpha_{6}$ conditional on the other variables in equation (3).

We estimate equation (3) based on firm-quarter observations. Because we estimate ExVOL using information from the firm's subsequent earnings announcements, ExVOL is likely correlated over time. Thus, we base $t$-statistics on regression residuals clustered by firm and quarter (Gow, Ormazabal, and Taylor 2010).

\section{SAMPLE, DATA, AND DESCRIPTIVE STATISTICS}

\section{Sample and Data}

We obtain option data from OptionMetrics, which reports end-of-day summary information on Chicago Board Options Exchange listed options on U.S. equities beginning in 1996. Our sample comprises firms in OptionMetrics that meet our sample selection criteria with data available to construct our variables. For each firm and day, OptionMetrics calculates implied volatility for standardized 30 - and 60-day call options. ${ }^{12}$ We obtain accounting data from

\footnotetext{
${ }^{12}$ Because prices of standardized options are weighted averages of prices of traded options with different maturities, mechanical differences in implied volatility relating to option time-to-maturity could affect our inferences. Untabulated findings from re-estimating the Table 3 analyses using traded option prices, which are available for 15,459 firm-quarters, reveal inferences that are the same as from the tabulated findings for COMOVE; the findings for $A N B E T A$ and $S A M E D A T E$ are consistent with the tabulated findings but there is evidence of reduced power.
} 
Compustat, and daily equity returns, the equal-weighted equity market return, and data to construct CAPM betas from CRSP. We require firms to have earnings announcement dates on $\mathrm{I} / \mathrm{B} / \mathrm{E} / \mathrm{S}$, and require 12 quarters (10 quarters) of data prior (subsequent) to each quarterly observation to construct our variables. ${ }^{13}$ Our criteria result in a sample of 83,331 firm-quarter observations for 3,827 firms from 1996 to 2010.

Our tests use one-day earnings announcement returns. However, several studies note that some Compustat earnings announcement dates are incorrect, and using an incorrect date can bias our tests and reduce their power. Thus, we follow DellaVigna and Pollet (2009) and compare $\mathrm{I} / \mathrm{B} / \mathrm{E} / \mathrm{S}$ and Compustat announcement dates and assume the earlier date is correct. We use the $\mathrm{I} / \mathrm{B} / \mathrm{E} / \mathrm{S}$ time stamp to determine whether the announcement occurred after the market close; when it does, we adjust the announcement date one trading day forward. ${ }^{14}$

\section{Descriptive Statistics}

Table 1 presents descriptive statistics for the variables we use to estimate equation (3). Panel A presents distributional statistics and reveals that the mean of ExVOL is 0.006 . A positive mean is consistent with, on average, a volatility risk premium associated with earnings announcements embedded in option prices. Untabulated statistics reveal that this mean is significantly different from zero $(t$-stat. $=2.73) .{ }^{15}$ The mean of COMOVE is -0.012 , which indicates that on average return volatility co-movement is greater at earnings announcements than during non-announcement periods. The mean of ANBETA is 0.102 , which is consistent with findings in prior research that CAPM betas tend to increase at earnings announcements, and with

\footnotetext{
${ }^{13}$ Requiring multiple quarters of data for each firm potentially introduces survivorship bias. We expect that larger, surviving firms have more non-diversifiable volatility risk, and thus larger risk premiums. However, although survivorship bias could affect the magnitude of the premium, our interest is in the relation between the premium and non-diversifiable volatility risk, not the magnitude of the premium.

${ }^{14}$ Section $\mathrm{V}$ discusses the robustness of our inferences to using alternative ways to identify announcement dates.

${ }^{15} \mathrm{We}$ use the term significant to denote statistical significance at the $p<0.05$ level based on a one-sided test when we have a signed prediction, and a two-sided test otherwise.
} 
the estimates in Hsieh, Jerris, and Kross (1999). The mean of SAMEDATE of 5.271 indicates that approximately 200 firms announce earnings on the same day. The mean of SIZE is 7.426, which indicates sample firms have an average market value of equity of $\$ 1,679.08$ million.

Panel B of Table 1 presents correlations for the variables; correlations in bold font are significantly different from zero. Consistent with our predictions, Panel B reveals that the volatility risk premium, ExVOL, is positively correlated with non-diversifiable volatility risk, COMOVE $($ Pearson $=0.311 ;$ Spearman $=0.357)$. ExVOL also is positively correlated with one of the other measures of non-diversifiable risk, SAMEDATE, and with SIZE (Pearson $=0.020$ and 0.306; Spearman $=0.012$ and 0.328 ). However, ExVOL is not significantly correlated with nondiversifiable price risk, $A N B E T A$ (Pearson and Spearman $=-0.010$ and -0.011 ). The correlations between both COMOVE and ExVOL and $|R E T|$ and $|H I S T R E T|$ are significantly negative, which is consistent with a possible mechanical relation between COMOVE and ExVOL attributable to $|R E T|$ and $\mid$ HISTRET $\mid$. The largest correlation is between COMOVE and $\mid$ HISTRET $\mid$ (Pearson =0.790; Spearman $=-0.792$ )

\section{FINDINGS: NON-DIVERSIFIABLE VOLATILITY RISK AND RISK PREMIUMS}

Table 2 presents means of our volatility risk premium proxy, ExVOL, by quintile of nondiversifiable volatility risk, COMOVE. Panel A reveals that firms with higher COMOVE have significantly larger ExVOL. The difference in mean ExVOL between the High and Low COMOVE quintiles is 0.436 , which is significantly different from zero $(t$-stat. $=39.72)$. Panel A also reveals that mean ExVOL increases monotonically across COMOVE quintiles from -0.226 to 0.201 , with negative means in the bottom two quintiles and positive means in the top three. These statistics reveal a significant positive relation between ExVOL and COMOVE, and are consistent with a volatility risk premium reflected in option prices only for firms whose options 
hedge volatility risk at earnings announcements, i.e., for earnings announcements that convey news about the market portfolio.

Table 2, Panel B, presents statistics analogous to those in Panel A using $E x V O L^{c s}$, which is based on the cross-sectional standard deviation of $I A V_{q}$ whereas $E x V O L$ is based on the standard deviation of a firm's $I A V_{q}$ over quarters $q$ to $q+9$. Thus, Panel B provides evidence on the extent to which the relation between ExVOL and COMOVE depends on using future information in constructing ExVOL. Panel B reveals statistics for ExVOL ${ }^{c s}$ across COMOVE quintiles that are very similar to those for ExVOL in Panel A, which indicates that the significant positive relation between ExVOL and COMOVE is not attributable to constructing ExVOL based on future information.

Table 3 presents summary statistics from estimating various versions of equation (3). The first column presents statistics when COMOVE is the only explanatory variable. As expected, the coefficient on COMOVE is positive and significantly different from zero $(t$-stat. $=27.04)$. This significant positive relation indicates that volatility risk premiums embedded in preannouncement option prices are significantly higher when the firm's earnings announcement poses greater non-diversifiable volatility risk, i.e., when the firm's return volatility co-moves more with market return volatility on the firm's quarterly earnings announcement day. ${ }^{16}$

The second column reports findings from a version of equation (3) that includes COMOVE and ANBETA, the increase in the firm's CAPM beta at earnings announcements. The column reveals that the coefficient on COMOVE is significantly positive $(t$-stat. $=27.18)$. It also

\footnotetext{
${ }^{16}$ COMOVE is based on the market index for the U.S. To investigate whether our findings extend to global market non-diversifiable volatility risk, we redefined COMOVE using as the market index the Dow Jones STOXX Global 1800 Index. Our sample firms are in the U.S. and by the time they announce earnings, it could be the following day elsewhere in the world. Thus, we use a two-day return on the Dow Jones STOXX Global 1800 Index - the day of and the day after the earnings announcement. Untabulated findings from estimating all versions of equation (3) using the redefined COMOVE reveal inferences identical to those we tabulate.
} 
reveals that the coefficient on ANBETA is significantly positive after controlling for COMOVE $(t$-stat. $=4.47)$. This finding suggests that the increase in CAPM beta at earnings announcements is associated with risk premiums embedded in option prices and that ExVOL reflects premiums associated with non-diversifiable price risk as well as non-diversifiable volatility risk.

The third column reports findings from a version of equation (3) that includes COMOVE, ANBETA, and SAMEDATE and reveals the same inferences relating to COMOVE and ANBETA as the second column (coef. $t$-stats. $=27.08$ and 4.45). It also reveals that the coefficient on the number of firms that have the same earnings announcement date as the firm, SAMEDATE, is not significantly different from zero $(t$-stat. $=1.24)$. This finding indicates that this generic measure of non-diversifiable risk is not significantly associated with risk premiums embedded in option prices, perhaps because SAMEDATE captures investor inattention or because ExVOL is designed to capture volatility risk premiums, not premiums for other unspecified types of risk.

The remaining columns of Table 3 sequentially add the firm's absolute one-day quarter $q$ earnings announcement return, $|R E T|$; the average absolute difference between the firm's one-day earnings announcement return and the market return over the 12 quarters prior to quarter $q$, |HISTRET|; and the natural logarithm of equity market value, SIZE. Most importantly, these columns confirm the inferences regarding COMOVE from the first three columns. That is, the coefficient on COMOVE is significantly positive in all specifications, although the $t$-statistic is smaller when $|H I S T R E T|$ is included ( $t$-stats. range from 6.44 to 25.98$)$. These columns also reveal that ANBETA's coefficient is significantly positive in all specifications, although its $t$ statistic also is smaller when $\mid$ HISTRET $\mid$ is included ( $t$-stats. range from 1.70 to 3.96$)$. Finally, column six reveals that when SIZE is added to the estimation, and thus when all control variables are included, SAMEDATE's coefficient is significantly positive, as predicted $(t$-stat. $=2.14)$. 
Columns four, five, and six also reveal that the coefficients on $\mid$ RET $\mid$ and $\mid$ HISTRET $\mid$ are significantly negative, and column six indicates that the coefficient on SIZE is significantly positive. The $t$-statistics for the coefficient on $\mid$ RET $\mid(\mid$ HISTRET $\mid)$ are $-13.39,-12.61$, and -11.64 (-11.62 and -8.44$)$, and that for the coefficient on SIZE is 16.20 . That SIZE is significantly positively related to ExVOL indicates that larger firms have larger volatility risk premiums. This finding is inconsistent with Ball and Kothari (1991), who find that smaller firms have larger increases in CAPM beta at earnings announcements. Nevertheless, the findings in column six indicate that COMOVE, ANBETA, and SAMEDATE reflect dimensions of non-diversifiable risk incremental to size.

\section{ADDITIONAL ANALYSES}

\section{Characteristics of Earnings Announcements}

Our primary tests assume that earnings news is released at the earnings announcement. However, some firms pre-announce bad news, some delay the announcement of bad news, and some give guidance prior to the announcement (Penman 1980; Kasznik and Lev 1995; Skinner 1997; Rogers, Skinner, and Van Buskirk 2009). The market reaction to good and bad news differs (Givoly and Palmon 1982; Chambers and Penman 1984; Skinner 1994; Kothari, Shu, and Wysocki 2009), and prior research finds differences in announcement equity returns for larger and smaller firms. In addition, our sample period includes the recent financial crisis, which could affect our inferences, and it is possible that the relation between COMOVE and ExVOL differs depending on whether many firms announce earnings on the same day. Thus, we determine whether our inferences from equation (3) relating to COMOVE, ANBETA, and SAMEDATE apply to these various subsamples of firms and announcements; we omit SIZE (SAMEDATE) from tests based on subsamples partitioned by SIZE (SAMEDATE). 
The findings are in Table 4, Panels A through F. Panel A presents findings for earnings announcements by firms with equity market value above (below) the annual sample median, i.e., Larger (Smaller) Firms. Panel B presents findings for announcements with good and bad earnings news, where Good News (Bad News) denotes that the announced earnings is above (below) the consensus analyst earnings forecast just prior to the earnings announcement. Panel C presents findings for earnings announcements partitioned by whether the firm provided an earnings forecast reported in the First Call Company Issued Guidelines database within 60 trading days before the announcement date. We label these Guidance and No Guidance. Panel D presents findings for earnings announcements after and before the market close, i.e., After Close and Before Close. Panel E presents findings for announcements before (after) January 1, 2006, which we label Pre Crisis (Post Crisis). Panel F presents findings for announcements with above (below) the median SAMEDATE for each quarter, which we label High (Low) SAMEDATE. Table 4 presents differences in the coefficients across subsamples; we have no predictions for these differences.

The findings in Table 4 reveal that COMOVE is significantly positively related to volatility risk premiums embedded in option prices in all subsamples. The $t$-statistics in Panels A through $\mathrm{F}$ range from 3.35 to 7.00 . These findings confirm those in Table 3 that the significant positive relation between non-diversifiable volatility risk and risk premiums embedded in option prices is not attributable to firm size, or to the characteristics of earnings announcements we examine. Table 4 also reveals that $A N B E T A$ and SAMEDATE are significantly related to volatility risk premiums in some subsamples, but not all. The coefficient on ANBETA is significantly positive for Smaller Firms, Bad News, No Guidance, Before Close, Pre Crisis, and Low SAMEDATE ( $t$-stats. range from 1.78 to 2.92). The coefficient on SAMEDATE is 
significantly positive for Larger Firms, Good News, Guidance, Before Close, Pre Crisis, and Post Crisis ( $t$-stats. range from 2.01 to 3.44$)$.

\section{Earnings Announcement Dates}

Incorrectly specifying the actual or expected earnings announcement date could confound our inferences because both affect our proxy for volatility risk premiums, ExVOL. The earnings announcement date affects $R E T_{q}$ in equation (1) because that is the date on which we measure the firm's announcement equity return. It also affects $I A V_{q}$ because our tests treat the actual announcement date as the announcement date expected by option traders. This section describes findings based on alternative approaches to identifying the actual and expected earnings announcement dates. None of these alternatives affects our inferences.

First, Cohen et al. (2007) develop a procedure to identify early, on-time, and late earnings announcements. We implement the Cohen et al. (2007) procedure to estimate a firm's expected earnings announcement date when calculating ExVOL. In particular, we analyze the distributions of each firm's earnings announcement dates for each fiscal quarter, and identify each announcement date as one of 63 days in the quarter, i.e., day 1 through day 63 . We then divide our sample into two six-year subperiods and use the median announcement date within each subperiod as the expected announcement date. We identify an earnings announcement as Ontime, Early, or Late if it occurs within one day of, before, or after the expected date.

Table 5 presents the findings. Because availability of option data results in a somewhat smaller sample than in Table 3, we present findings for all announcements in the first column. The inferences are almost the same as those in Table 3 in that the coefficients on COMOVE and SAMEDATE are significantly positive ( $t$-stats. $=5.35$ and 2.24$)$. The coefficient on ANBETA is positive, but not significantly different from zero $(t$-stat. $=1.58)$. More importantly, Table 5 
reveals that our inference relating to COMOVE is unaffected by using expected announcement dates. In particular, the coefficient on COMOVE is significantly positive for Early, On-Time, and Late announcements $(t$-stats. $=3.02,4.94$, and 4.51). ANBETA $(S A M E D A T E)$ also is significantly positively related to ExVOL for On-Time (Early and Late) announcements.

Second, Cohen et al. (2007) find that $87 \%$ of actual announcements occur within the 11day window surrounding the expected announcement date. Thus, we recalculate $I A V_{q}$ using option prices from day $t-10$ to day $t-6$, where day $t$ is the announcement date, which avoids using prices that could reflect early earnings announcements, and re-estimate equation (3). The untabulated findings reveal the same inferences revealed by Table 3 in that COMOVE has a significantly positive relation with ExVOL, with and without the additional control variables.

Third, $R E T_{q}$ is the one-day earnings announcement return because earnings news is reflected in equity prices quickly (Patell and Wolfson 1984). However, findings based on returns over longer windows that include the announcement also should be consistent with our predictions. Although longer window tests likely suffer from reduced power, using longer windows helps ensure that $R E T_{q}$ includes the announcement return. Thus, we re-estimate equation (3) alternatively using measures of ExVOL based on three-day and seven-day returns, i.e., returns from days $t-1$ to $t+1$ and days $t-3$ to $t+3$. Fourth, incorrectly identifying the actual announcement date could inflate $E x V O L$ because $R E T_{q}$ will be understated. However, the findings in Table 3 reveal that volatility risk premiums are larger for firms with more nondiversifiable volatility risk, which tend to be larger firms whose earnings announcement dates are more likely to be correctly identified. Nonetheless, we alternatively treat as the announcement date the day with the firm's largest absolute return between day $t-5$ and $t+5$. The untabulated findings from both of these alternatives reveal the same inferences as our tabulated findings. 
Finally, we investigate whether our non-diversifiable risk measures are positively associated with risk premiums during non-announcement periods. In the absence of earnings news we do not expect a positive relation. To test this, we generate pseudo earnings announcement dates by subtracting from the firm's actual announcement date a random number of trading days and re-estimating equation (3). The random numbers are uniformly distributed over 30 to 50, which ensures separation between the pseudo and actual announcement dates. For example, if the random number for a firm is 40 , we set the firm's pseudo earnings announcement date to 40 trading days prior to the actual announcement. We then re-estimate ExVOL and equation (3) based on the pseudo announcement dates. The untabulated findings do not reveal a significant positive relation between our non-diversifiable risk measures and ExVOL.

\section{Alternative Measures of Non-diversifiable Volatility Risk}

We next consider alternative measures of non-diversifiable volatility risk. The first measure captures covariation between the implied volatilities of the announcing firm and the market. Specifically, we first construct VIXCOMOVE in the same way that we construct COMOVE, but focus on the co-movement of the firm's implied volatility and the implied volatility of the S\&P500 index, i.e., the VIX.

$$
\operatorname{VIXCOMOVE}_{q}=-1 \times\left\{\left|\Delta I V_{t}-\Delta V I X_{t}\right|_{E A}-\left|\Delta I V_{t}-\Delta V I X_{t}\right|_{N E A}\right\},
$$

where $\Delta I V_{t}\left(\Delta V I X_{t}\right)$ is the one-day percentage change in the firm's implied volatility (the VIX). As in equation (4), $\mid \Delta I V_{t}-\Delta V I X_{t \mid E A}$ and $\left|\Delta I V_{t}-\Delta V I X_{t}\right|_{N E A}$ are averages over the 12 quarters prior to quarter $q$, and higher $V I X C O M O V E_{q}$ indicates greater non-diversifiable volatility risk at the firm's earnings announcement.

Second, following Carr and $\mathrm{Wu}$ (2008), we construct VOLBETA in the same way that we construct $A N B E T A$ except that we capture non-diversifiable volatility risk rather than non- 
diversifiable price risk by using the firm's and the market's absolute returns, $\left|R E T_{t}\right|$ and $\left|M K T_{t}\right|$, rather than the signed returns. Specifically, $\operatorname{VOLBETA}_{q} \equiv \gamma_{3}$ is the change in the volatility beta at earnings announcements.

$$
\left|R E T_{t}\right|=\gamma_{0}+\gamma_{1}\left|M K T_{t}\right|+\gamma_{2} \text { AnnDate }_{t}+\gamma_{3}\left|M K T_{t}\right|^{*} \text { AnnDate }_{t}+\varepsilon_{t}
$$

The other two measures do not employ stock returns and are intended to identify bellwether firms. The first is SP500, which equals one for firms that are included in the S\&P500 Index and zero otherwise, and is motivated by the definition of bellwether firms in Anilowski, Feng, and Skinner (2007). Following Bonsall, Bozanic, and Fischer (2013), the second is BELLWETHER, which equals one for firms in the upper quartile of firms in terms of the macroeconomic content of their earnings surprises, and zero otherwise.${ }^{17}$ We use these four variables as alternatives for COMOVE in equation (3), and omit the three control variables.

Table 6 presents the results. Panel A (B) presents results for the two returns-based (nonreturns-based) measures. Panel A reveals that VIXCOMOVE and VOLBETA are both significantly positively related to volatility risk premiums embedded in option prices, ExVOL, regardless of whether ANBETA and SAMEDATE are included in the equation. Panel B reveals the same inferences for SP500 and BELLWETHER; both are significantly positively related to ExVOL, regardless of whether ANBETA and SAMEDATE are included in the equation. Table 6 supports our inferences that some earnings announcements pose non-diversifiable volatility risk and investors pay premiums for options that hedge volatility risk at earnings announcements.

\footnotetext{
${ }^{17}$ We calculate BELLWETHER following the two-stage firm-specific regression procedure in Bonsall, Bozanic, and Fischer (2013), but applied to earnings surprises rather than earnings forecasts. In the first stage, we estimate regressions of earnings, scaled by assets, on a vector of lagged macroeconomic forecasts from the Federal Reserve Bank of Philadelphia's Survey of Professional Forecasts to obtain fitted values of the firm's earnings based on the forecasts and residuals. We estimate two sets of second-stage regressions-one with standardized unexplained earnings (SUE) as the dependent variable and one with earnings. In both sets, the explanatory variables are the fitted values and residuals from the first-stage regressions. For SUE (earnings), we calculate the ratio of the variation in SUE (earnings) explained by the fitted values to that explained by the residuals. BELLWETHER firms are those for which the difference between the SUE and earnings ratios in each calendar quarter is in the top quartile.
} 


\section{Alternative Measure of Risk Premiums Embedded in Option Prices}

We construct ExVOL based on the idea that there is a premium embedded in preannouncement option prices that reflects compensation to option writers for bearing nondiversifiable volatility risk associated with the announcement. We expect this premium to disappear after the announcement because any market volatility associated with the announcement is realized and is no longer a risk. Thus, the risk premium pattern we predict around earnings announcements should result in a negative correlation between COMOVE and returns to option straddle positions over the three-day earnings announcement window. We use these straddle returns as an alternative proxy for volatility risk premiums. An option straddle position requires purchasing at-the-money call and put options on the same firm's equity. The payoff to this pair of options is increasing in the absolute price change of the firm's equity, but is insensitive to the direction of the change. ${ }^{18}$ Thus, we calculate returns from taking a long (short) straddle position in firms in the lowest (highest) quintile of COMOVE. The return to this strategy represents the risk premium embedded in option prices associated with non-diversifiable volatility risk, as measured by COMOVE.

Table 7 presents the findings and confirms our primary inferences based on ExVOL. In particular, Panel A reveals that three-day earnings announcement straddle returns are monotonically decreasing across COMOVE quintiles. The return to the hedged High - Low COMOVE straddle position is $-0.040(t$-stat. $=-5.09)$, which indicates that the volatility risk premium during the three-day announcement window is 4\%. Panel B presents findings from estimating equation (3) using straddle returns as the volatility risk premium proxy rather than ExVOL. Panel B reveals that COMOVE is significantly negatively related to the straddle returns

\footnotetext{
${ }^{18}$ We do not use straddle returns as our primary measure of risk premiums because many of our sample firms do not have both call and put prices, which are required to calculate straddle returns.
} 
regardless of whether $A N B E T A$ and $S A M E D A T E$ are included in the equation. ${ }^{19}$ Panel $\mathrm{C}$ presents findings analogous to those in Panel B but based on announcement-specific straddle returns, i.e., the straddle return for the three-day announcement window minus the straddle return during a random three-day pseudo-announcement window prior to the actual announcement.

\section{CONCLUSION}

We examine whether earnings announcements pose non-diversifiable volatility risk that commands a risk premium. Prior research does not establish a link between non-diversifiable price risk associated with earnings announcements and risk premiums measured using realized announcement equity returns. Non-diversifiable price risk and non-diversifiable volatility risk are conceptually and empirically distinct types of risk. Price risk is associated with the first moment of the return distribution and volatility risk is associated with the second moment. Each type of risk can have a non-diversifiable component to the extent the security's return comoves with the market return, for price risk, or the security's return volatility comoves with market return volatility, for volatility risk.

For a sample of over 80,000 quarterly earnings announcements between 1996 and 2010 by firms with publicly traded equity and traded options, consistent with option-pricing theory, we find that prices of options with more exposure to non-diversifiable volatility risk at earnings announcements reflect larger volatility risk premiums. Option prices reflect these premiums because option payoffs increase in the realization of market volatility, which makes them effective hedges of market volatility risk. Our findings indicate that investors pay premiums to hedge non-diversifiable volatility risk associated with earnings announcements.

\footnotetext{
${ }^{19}$ Note that COMOVE's coefficient is negative because higher COMOVE reflects greater non-diversifiable volatility risk, which is associated with more negative straddle returns; the negative straddle returns effectively represent the premium paid to hedge that risk.
} 
Taken together, our findings establish a significant positive relation between nondiversifiable volatility risk and risk premiums at earnings announcements. The findings enhance our understanding of the information content of earnings announcements by showing that earnings announcements pose non-diversifiable volatility risk that commands a risk premium. This result suggests that investors view earnings announcements as a source of uncertainty about market volatility and pay premiums to hedge this uncertainty. 


\section{Appendix A}

\section{Construction of Implied Earnings Announcement Volatility}

The model we use to estimate implied earnings announcement volatility, $I A V$, expresses implied volatility as the sum of baseline volatility and volatility associated with the anticipated change in equity prices at the earnings announcement, averaged over the remaining option life (Merton 1973; Patell and Wolfson 1979; 1981; Dubinsky and Johannes 2006; Broadie, Chernov, and Johannes 2007; among others). This leads to equation (A1):

$$
\sigma_{t, T}^{2}=\sigma^{2}+T^{-1} \sigma_{E A}^{2},
$$

where $\sigma_{t, T}^{2}$ is volatility implied by pre-announcement day $t$ option prices, $\sigma^{2}$ is implied baseline volatility in annualized units, $\sigma_{E A}^{2}$ is implied volatility associated with anticipated price changes on the earnings announcement day, and $T$ is the number of trading days until option maturity.

Equation (A1) is identical to the representation of implied volatility in Patell and Wolfson (1981), except that we assume the increase in equity volatility associated with the earnings announcement occurs on the announcement day rather than over potentially several days surrounding the announcement. ${ }^{20}$ This assumption is consistent with extant literature documenting rapid equity price changes at earnings announcements. It also permits a direct comparison of expected and realized announcement volatility, which enables us to construct a proxy for volatility risk premiums at earnings announcements.

Rearranging equation (A1) shows that expected volatility on the earnings announcement day for quarter $q$ can be expressed as:

$$
I A V_{q}=\sqrt{\sigma_{E A}^{2}+\sigma^{2} / 252}
$$

\footnotetext{
${ }^{20}$ In the notation of Patell and Wolfson (1981), we assume $\tau=1$, and thus that implied volatility reverts to baseline volatility on the day after the announcement.
} 
We divide $\sigma^{2}$ by 252 , the number of trading days in a year, to capture the contribution of baseline volatility to total expected volatility on the announcement day. The day after the announcement, implied volatility reflects only baseline volatility, i.e., $\sigma_{E A}^{2}=0$ and total implied volatility $=\sigma^{2} .^{21}$

Because both implied volatilities in equation (A1), $\sigma^{2}$ and $\sigma_{E A}^{2}$, are unknown, estimating them requires use of two pre-announcement option prices. We use prices of the firm's 30 - and 60-day standardized at-the-money call options traded on pre-announcement day $t .{ }^{22} \mathrm{We}$ first estimate $\sigma_{E A}^{2}$ using the following expression derived from equation (A1).

$$
\sigma_{E A}^{2}=\frac{\sigma_{t, T_{1}}^{2}-\sigma_{t, T_{2}}^{2}}{T_{1}^{-1}-T_{2}^{-1}}=\frac{\sigma_{t, 30}^{2}-\sigma_{t, 60}^{2}}{\frac{252}{30}-\frac{252}{60}}
$$

Our estimation of $\sigma_{E A}^{2}$ assumes investors anticipate the earnings announcement at some point between the date of the option prices we use to estimate equation (A3) and option expiration. ${ }^{23}$ We then use our estimate of $\sigma_{E A}^{2}$ and equation (A1) to estimate $\sigma^{2}$. To reduce measurement error in calculating $I A V_{q}$ in equation (A2) we use the five-day averages of $\sigma_{E A}^{2}$ and $\sigma^{2}$ implied by option prices on days $t-6$ to $t-2$, where day $t$ is the earnings announcement date.

\footnotetext{
${ }^{21}$ Equity returns also can be subject to stochastic volatility. To the extent investors anticipate a volatility regime shift at earnings announcements $I A V$ could be larger than expected announcement volatility, and thus our volatility risk premiums could be overstated. However, our interest is in the relation between the risk premiums and nondiversifiable volatility risk, not the magnitude of the premiums.

${ }^{22}$ We use standardized options to mitigate concerns associated with estimating implied volatility from multiple options with varying expiration dates (Rogers, Skinner, and Van Buskirk 2009). We use at-the-money options because Whaley (1986) finds that implied volatilities derived from the Black and Scholes (1974) formula are most representative of realized volatility for at-the-money options.

${ }^{23}$ Our measure reflects anticipated price changes over the next 30 days, attributable to earnings announcements or to other anticipated events. To the extent investors' expected earnings announcement date is outside the 30- and 60-day option maturity window, our estimates of $\sigma_{E A}^{2}$ and the volatility risk premium are likely to be understated. However, Section V reports that our inferences are unaffected by using expected announcement dates as in Cohen et al. (2007). Untabulated findings reveal that our inferences also are unaffected by using an ex post measure of implied announcement volatility based on option prices just before and just after the announcement as in Patell and Wolfson (1981) to mitigate concerns about other anticipated events.
} 


\section{Appendix B}

\section{Variable Definitions}

- $A N B E T A_{q}$ is the difference in the firm's CAPM beta during earnings announcement and nonannouncement periods, calculated as $\beta_{3}$ from the following firm-specific regression estimated over the 12 quarters prior to quarter $q$ :

$$
R_{E T}=\beta_{0}+\beta_{1} M K T_{t}+\beta_{2} \text { AnnDate }_{t}+\beta_{3} M K T_{t}^{*} \text { AnnDate }_{t}+\varepsilon_{t}
$$

where $R E T_{t}$ is the firm's equity return on day $t, M K T_{t}$ is the value-weighted equity market return, and AnnDate $_{t}$ is an indicator variable that equals one on days within the three-day window of quarterly earnings announcements, i.e., days $t-1, t$, and $t+1$ relative to earnings announcement day $t$, and zero otherwise.

- BELLWETHER is an indicator variable that equals one for firms in the upper quartile of firms in terms of the macroeconomic content of their earnings surprises, calculated following Bonsall, Bozanic, and Fischer (2013), and zero otherwise.

- $\mathrm{COMOVE}_{q}$ is the difference in co-movement of the firm's equity return volatility and the equity market return volatility between earnings announcement days and non-announcement days.

$$
\mathrm{COMOVE}_{q}=-1 \times\left\{|| R E T_{t}|-| M K T_{t}||_{E A}-\left.|| R E T_{t}|-| M K T_{t}\right|_{N E A}\right\}
$$

where $E A(N E A)$ denotes the average co-movement on earnings announcement (nonannouncement) days for the 12 quarters prior to quarter $q$.

- ExVOL is excess implied earnings announcement volatility calculated as

$$
\operatorname{ExVOL}_{q} \equiv 1-\operatorname{sdev}\left(\frac{R E T_{q}}{I A V_{q}}\right)
$$

where sdev denotes standard deviation, which we calculate over quarters $q$ to $q+9$.

- $\left|H I S T R E T_{q}\right|$ is $\mid R E T_{t}-M K T_{t \mid E A}$, i.e., the average of the absolute difference between $R E T_{t}$ and $M K T_{t}$ on each earnings announcement date over the 12 quarters prior to quarter $q$.

- $I A V_{q}$ is implied announcement volatility, i.e., the standard deviation of the firm's one-day quarter $q$ earnings announcement return implied by prices of the firm's traded options. $I A V_{q}=\sqrt{\sigma_{E A}^{2}+\sigma^{2} / 252}$ where $\sigma_{E A}^{2}$ is implied volatility associated with the earnings announcement day, $\sigma^{2}$ is implied baseline volatility expressed in annualized units, and 252 is the number of trading days in a year. We estimate $\sigma_{E A}^{2}$ and $\sigma^{2}$ using pre-announcement prices of the firm's 30- and 60-day standardized at-the-money call options. To reduce measurement error in calculating $I A V_{q}$, we use the five-day averages of $\sigma_{E A}^{2}$ and $\sigma^{2}$ implied by option prices on days $t-6$ to $t-2$, where day $t$ is the earnings announcement date. See Appendix A for further details.

- $R E T_{q}$ is the firm's one-day quarter $q$ realized earnings announcement return; $\left|R E T_{q}\right|$ is its absolute value.

- $S_{A M E D A T E}$ is the natural logarithm of the number of firms in the Compustat database that in quarter $q$ had the same earnings announcement date as the firm.

- $S I Z E_{q}$ is the natural logarithm of firm's market value of equity at the end of quarter $q-1$. 
- SP500 is an indicator variable that equals one for firms that are included in the S\&P500 Index and zero otherwise.

- VIXCOMOVE $E_{q}$ equals the difference in co-movement of the firm's implied volatility and the implied volatility of S\&P500 index options, i.e., the VIX, between earnings announcement days and non-announcement days.

$$
V I X C O M O V E_{q}=-1 \times\left\{\left|\Delta I V_{t}-\Delta V I X_{t}\right|_{E A}-\left|\Delta I V_{t}-\Delta V I X_{t}\right|_{N E A}\right\}
$$

where $\Delta I V_{t}$ is the percentage change in the firm's implied volatility on the earnings announcement day relative to the day before the announcement and $\triangle V I X_{t}$ is the corresponding change in the VIX. EA (NEA) denotes the average co-movement on earnings announcement (non-announcement) days for the 12 quarters prior to quarter $q$.

- $V_{\text {OLBETA }}$ is the difference in the firm's volatility beta during earnings announcement and non-announcement periods, calculated as $\gamma_{3}$ from the following firm-specific regression estimated over the 12 quarters prior to quarter $q$ :

$$
\mid \text { RET }_{t}\left|=\gamma_{0}+\gamma_{1}\right| M K T_{t} \mid+\gamma_{2} \text { AnnDate }_{t}+\gamma_{3} \mid \text { MKT }\left._{t}\right|^{*} \text { AnnDate }_{t}+\varepsilon_{t}
$$

where $\left|R E T_{t}\right|$ is the firm's absolute equity return on day $t,\left|M K T_{t}\right|$ is the absolute valueweighted equity market return, and AnnDate $t_{t}$ is an indicator variable that equals one on days within the three-day window of quarterly earnings announcements, i.e., days $t-1, t$, and $t+1$ relative to earnings announcement day $t$, and zero otherwise. 


\section{References}

Anilowski, C., M. Feng, and D. Skinner. 2007. Does earnings guidance affect market returns? The nature and information content of aggregate earnings guidance. Journal of Accounting and Economics 44: 36-63.

Baginski, S. 1987. Intraindustry information transfers associated with management forecasts of earnings. Journal of Accounting Research 25: 196-216.

Ball, R., and P. Brown. 1968. An empirical evaluation of accounting income numbers. Journal of Accounting Research 6: 159-177.

Ball, R., and S. P. Kothari. 1991. Security returns around earnings announcements. The Accounting Review 66: 718-738.

Ball, R., G. Sadka, and R. Sadka. 2009. Aggregate earnings and asset prices. Journal of Accounting Research 47: 1097-1133.

Bansal, R., and A. Yaron. 2004. Interpretable asset markets. European Economic Review 49: 531-560.

Bansal, R., V. Khatchatrian, and A. Yaron. 2005. Risks for the long run: A potential resolution of asset pricing puzzles. Journal of Finance 59: 1481-1509.

Bansal, R., D. Kiku, I. Shaliastovich, and A. Yaron. 2012. Volatility, the macroeconomy, and asset prices. Working paper, NBER.

Beaver, W. 1968. The information content of annual earnings announcements. Journal of Accounting Research 6: 67-92.

Black, F. 1975. Fact and fantasy in the use of options. Financial Analyst Journal: 36-72.

Black, F., and M. Scholes. 1974. The effects of dividend yield and dividend policy on common stock prices and returns. Journal of Financial Economics 1: 1-22. 
Bollerslev, T., G. Tauchen, and H. Zhou. 2009. Expected stock returns and variance risk premia. Review of Financial Studies 22: 4463-4492.

Bonsall, S. B. IV, Z. Bozanic, and P. E. Fischer. 2013. What do management earnings forecasts convey about the macroeconomy? Journal of Accounting Research 51: 225-266.

Broadie, M., M. Chernov, and M. Johannes. 2007. Model specification and risk premia: Evidence from futures options. Journal of Finance 62: 1453-1490.

Broadie, M., M. Chernov, and M. Johannes. 2009. Understanding index option returns. Review of Financial Studies 22: 4493-4529.

Chambers, A., and S. Penman. 1984. Timeliness of reporting and the stock price reaction to earnings announcements. Journal of Accounting Research 22: 21-47.

Cohen, D. A., A. Dey, T. Z. Lys, and S. V. Sunder. 2007. Earnings announcement premia and limits to arbitrage. Journal of Accounting and Economics 43: 153-180.

Cready, W., and U. Gurun. 2010. Aggregate market reaction to earnings announcements. Journal of Accounting Research 48: 289-334.

Cready, W., and U. Gurun. 2009. Market return and aggregate earnings news. Working paper, University of Texas at Dallas.

DellaVigna, S., and J. Pollet. 2009. Investor inattention and Friday earnings announcements. Journal of Finance 64: 709-749.

Dubinsky, A., and M. Johannes. 2006. Fundamental uncertainty, earnings announcements and equity prices. Working paper, Columbia University.

Eades, K.M., R. Hess, and E. Kim. 1985. Market rationality and dividend announcements. Journal of Financial Economics 14: 423-449. 
Easley, D., M. O’Hara, and P. Srinivas. 1998. Option volume and stock prices: evidence on where informed traders trade. Journal of Finance 53: 431-465.

Elton, J. 1999. Expected return, realized return, and asset pricing tests. Journal of Finance 54: 1199-1220.

Epstein, L., and S. Turnbull. 1980. Asset prices and the temporal resolution of uncertainty. Journal of Finance 35: 627-643.

Fama, E., and K. French. 2004. The capital asset pricing model: Theory and evidence. Journal of Economic Perspectives 18: 25-46.

Foster, G. 1981. Intra-industry information transfers associated with earnings release. Journal of Accounting and Economics 3: 201-232.

Givoly, D., and D. Palmon. 1982. Timeliness of annual earnings announcements: Some empirical evidence. The Accounting Review 57: 486-508.

Gow, I. D., G. Ormazabal, and T. J. Taylor. 2010. Correcting for cross-sectional and time-series dependence in accounting research. The Accounting Review 85: 483-512.

Han, J., J. Wild, and K. Ramesh. 1989. Managers' earnings forecasts and intra-industry information transfers. Journal of Accounting and Economics 11: 3-33.

Hsieh, S., S. Jerris, and W. Kross. 1999. Quarterly earnings announcements and market risk. Journal of Business Finance and Accounting 26 (3): 313-336.

Hirshleifer, Lim, and Teoh. 2009. Driven to distraction: Extraneous events and underreaction to earnings news. Journal of Finance 64: 2289-2325.

Jackwerth, J., and M. Rubenstein. 1996. Recovering probability distributions from option prices. Journal of Finance 51: 1611-1631. 
Jackwerth, J. 2000. Recovering risk aversion from option prices and realized returns. Review of Financial Studies 13: 433-451.

Johnson, T. and E. So. 2012. The option to stock volume ratio and future returns. Journal of Financial Economics 106: 262-286.

Kalay, A., and U. Loewenstein. 1985. Predictable events and excess returns: The case of dividend announcements. Journal of Financial Economics 14: 423-449.

Kasznik, R., and B. Lev. 1995. To warn or not to warn: Management disclosures in the face of an earnings surprise. The Accounting Review 70: 113-134.

Kim, O., and R. Verrecchia. 1994. Liquidity and volume around earning announcements. Journal of Accounting and Economics 17: 41-67.

Kothari, S., J. Lewellen, and J. Warner. 2006. Stock returns, aggregate earnings surprises, and behavioral finance. Journal of Financial Economics 79: 537-568.

Kothari, S., S. Shu, and P. Wysocki. 2009. Do managers withhold bad news? Journal of Accounting Research 47: 241-276.

Lintner, J. 1965. The valuation of risk assets and the selection of risky investments in stock portfolios and capital budgeting. Review of Economics and Statistics 47: 13-37.

Lustig, H., and S. Van Nieuwerburgh. 2008. The returns to human capital: Good news on wall street is bad news on main street. Review of Financial Studies 21: 2097-2137.

Merton, R. 1973. The theory of rational option pricing. Bell Journal of Economics and Management Science 4: 141-183.

Pan, J. 2002. The jump-risk premia implicit in options: evidence from an integrated time-series study. Journal of Financial Economics 63: 3-50. 
Pan, J., and A. Poteshman. 2006. The information in option volume for future stock prices. Review of Financial Studies 19: 871-908.

Patell, J., and M. Wolfson. 1979. Anticipated information releases reflected in call option prices. Journal of Accounting and Economics 2: 117-40.

Patell, J., and M. Wolfson. 1981. The ex ante and ex post price effects of quarterly earnings announcements reflected in option and stock prices. Journal of Accounting Research 2: 434458.

Patell, J., and M. Wolfson. 1984. The intraday speed of adjustment of stock prices to earnings and dividend announcements. Journal of Financial Economics 13: 223-252.

Patton, A., and M. Verardo. 2012. Does beta move with news? Firm-specific information flows and learning about profitability. Review of Financial Studies 25: 2789-2839.

Penman, S. 1980. An empirical investigation of the voluntary disclosure of corporate earnings forecasts. Journal of Accounting Research 18: 132-160.

Rogers, J., D. Skinner, and A. Van Buskirk. 2009. Earnings guidance and market uncertainty. Journal of Accounting and Economics 48: 90-109.

Sharpe, W. 1964. Capital asset prices: A theory of market equilibrium under conditions of risk. Journal of Finance 19: 425-442.

Skinner, D. 1994. Why firms voluntarily disclose bad news. Journal of Accounting Research 32: $38-60$.

Skinner, D. 1997. Earnings disclosures and stockholder lawsuits. Journal of Accounting and Economics 23: 249-282.

Whaley, R 1986. Valuation of American futures options: Theory and empirical tests. Journal of Finance 10: 127-150. 
TABLE 1

Descriptive Statistics and Correlations

Panel A: Descriptive Statistics

\begin{tabular}{crrr} 
& Mean & Median & StdDev \\
\cline { 2 - 4 } ExVOL & 0.006 & 0.104 & 0.487 \\
COMOVE & -0.012 & -0.010 & 0.010 \\
ANBETA & 0.102 & 0.054 & 1.371 \\
SAMEDATE & 5.271 & 5.434 & 0.743 \\
$|R E T|$ & 4.868 & 3.183 & 5.012 \\
$\mid$ HISTRET $\mid$ & 4.739 & 4.156 & 2.843 \\
SIZE & 7.426 & 7.256 & 1.502
\end{tabular}

Panel B: Pearson (Spearman) Correlations Above (Below) the Diagonal

\begin{tabular}{|c|c|c|c|c|c|c|c|}
\hline & ExVOL & COMOVE & $A N B E T A$ & SAMEDATE & $|R E T|$ & |HISTRET & SIZE \\
\hline ExVOL & & 0.311 & -0.010 & 0.020 & -0.232 & -0.340 & 0.306 \\
\hline COMOVE & 0.357 & & -0.156 & 0.023 & -0.294 & -0.790 & 0.249 \\
\hline ANBETA & -0.011 & -0.157 & & 0.013 & 0.010 & 0.037 & -0.003 \\
\hline SAMEDATE & 0.012 & 0.023 & 0.004 & & -0.016 & -0.004 & -0.032 \\
\hline$|R E T|$ & -0.249 & -0.309 & 0.009 & -0.021 & & 0.329 & -0.175 \\
\hline |HISTRET| & -0.404 & -0.792 & 0.034 & -0.001 & 0.359 & & -0.358 \\
\hline$S I Z E$ & 0.328 & 0.249 & -0.002 & -0.031 & -0.174 & -0.317 & \\
\hline
\end{tabular}

Panel A provides descriptive statistics and Panel B provides Pearson and Spearman correlation coefficients. Bolded amounts in Panel B indicate significance at the 5 percent level. The sample consists of 83,331 firm-quarters from 1996 to 2010. See Appendix B for variable descriptions. 
TABLE 2

Portfolio Average ExVOL by COMOVE Quintiles

\section{Panel A: ExVOL by COMOVE Quintile}

\begin{tabular}{crrrrrr} 
& $1($ Low $)$ & 2 & 3 & 4 & $5($ High $)$ & High - Low \\
\cline { 2 - 7 } Mean & -0.226 & -0.090 & 0.029 & 0.144 & 0.210 & 0.436 \\
$t$-statistic & $(-15.50)$ & $(-6.99)$ & $(2.02)$ & $(15.07)$ & $(22.55)$ & $(39.72)$
\end{tabular}

Panel B: $\operatorname{EXVOL}^{\text {cs }}$ by COMOVE Quintile

\begin{tabular}{cccccrr} 
& 1 (Low) & 2 & 3 & 4 & 5 (High) & High - Low \\
\cline { 2 - 7 } Mean & -0.214 & -0.091 & 0.022 & 0.128 & 0.215 & 0.429 \\
$t$-statistic & $(-7.30)$ & $(-3.81)$ & $(0.96)$ & $(6.20)$ & $(12.39)$ & $(22.54)$
\end{tabular}

The table presents time-series means of earnings announcement risk premiums, ExVOL, for quintiles of non-diversifiable earnings announcement volatility risk, COMOVE. ExVOL ${ }^{c s}$ is the same as ExVOL, except that ExVOL ${ }^{c s}$ uses the cross-sectional standard deviation of $I A V_{q}$ rather than the standard deviation of the firm-specific $I A V_{q}$ over for quarters $q$ to $q+9$. $t$-statistics are based on the time-series distribution. The sample consists of 83,331 firm-quarters from 1996 to 2010. See Appendix B for variable descriptions. 
TABLE 3

Announcement Volatility Risk Premiums and Non-diversifiable Earnings Announcement Risk

\begin{tabular}{|c|c|c|c|c|c|c|c|}
\hline & $\begin{array}{l}\text { Pred. } \\
\text { Sign }\end{array}$ & (1) & (2) & (3) & (4) & (5) & (6) \\
\hline Intercept & (?) & $\begin{array}{l}0.182^{* * *} \\
(15.90)\end{array}$ & $\begin{array}{l}0.184^{* * * *} \\
(16.11)\end{array}$ & $\begin{array}{l}0.142^{* * * *} \\
(3.92)\end{array}$ & $\begin{array}{l}0.194^{* * *} \\
(5.32)\end{array}$ & $\begin{array}{l}0.252^{* * * *} \\
(6.75)\end{array}$ & $\begin{array}{l}-0.345^{* * *} \\
(-5.62)\end{array}$ \\
\hline COMOVE & $(+)$ & $\begin{array}{l}14.606^{* * *} \\
(27.04)\end{array}$ & $\begin{array}{l}14.896^{* * *} \\
(27.18)\end{array}$ & $\begin{array}{l}14.881^{* * *} \\
(27.08)\end{array}$ & $\begin{array}{l}12.732 * * * \\
(25.98)\end{array}$ & $\begin{array}{l}4.967^{* * * *} \\
(6.44)\end{array}$ & $\begin{array}{l}5.038^{* * *} \\
(6.77)\end{array}$ \\
\hline ANBETA & $(+)$ & & $\begin{array}{l}0.014 * * * \\
(4.47)\end{array}$ & $\begin{array}{l}0.014^{* * * *} \\
(4.45)\end{array}$ & $\begin{array}{l}0.012^{* * *} \\
(3.96)\end{array}$ & $\begin{array}{l}0.005^{*} \\
(1.84)\end{array}$ & $\begin{array}{l}0.005^{*} \\
(1.70)\end{array}$ \\
\hline SAMEDATE & $(+)$ & & & $\begin{array}{c}0.008 \\
(1.24)\end{array}$ & $\begin{array}{r}0.007 \\
(1.12)\end{array}$ & $\begin{array}{r}0.009 \\
(1.48)\end{array}$ & $\begin{array}{l}0.014^{* *} \\
(2.14)\end{array}$ \\
\hline$|R E T|$ & (?) & & & & $\begin{array}{l}-0.015^{* * *} \\
(-13.39)\end{array}$ & $\begin{array}{l}-0.013^{* * *} \\
(-12.61)\end{array}$ & $\begin{array}{l}-0.011^{* * *} \\
(-11.64)\end{array}$ \\
\hline $\mid$ HISTRET $\mid$ & (?) & & & & & $\begin{array}{l}-0.037^{* * *} \\
(-11.62)\end{array}$ & $\begin{array}{l}-0.026^{* * *} \\
(-8.44)\end{array}$ \\
\hline SIZE & (?) & & & & & & $\begin{array}{l}0.069^{* * * *} \\
(16.20)\end{array}$ \\
\hline $\begin{array}{l}\text { Adj R- } \\
\text { Squared }\end{array}$ & & 0.097 & 0.098 & 0.098 & 0.120 & 0.136 & 0.176 \\
\hline
\end{tabular}

The table presents the summary statistics for regressions of earnings announcement risk premiums, ExVOL, on measures of nondiversifiable earnings announcement risk. The sample of consists of 83,331 firm-quarters from 1996 to 2010. $t$-statistics based on standard errors clustered by firm and quarter are shown in parentheses. See Appendix B for variable descriptions. ***, **, and * denote significance at the $0.01,0.05$, and 0.10 levels, based on a two-sided test. 
TABLE 4

Non-Diversifiable Earnings Announcement Risk and Risk Premiums by Sample Partitions

$$
\begin{aligned}
\operatorname{ExVOL}_{q}= & \alpha_{0}+\alpha_{1} \text { COMOVE }_{q}+\alpha_{2} \text { ANBETA }_{q}+\alpha_{3} \text { SAMEDATE }_{q} \\
& +\alpha_{4}\left|R E T_{q}\right|+\alpha_{5}\left|\operatorname{HISTRET}_{q}\right|+\alpha_{6} \operatorname{SIZE}_{q}+\varepsilon_{q}
\end{aligned}
$$

\begin{tabular}{|c|c|c|c|}
\hline & Larger Firms & Smaller Firms & $\begin{array}{l}\text { Coefficient } \\
\text { Differences }\end{array}$ \\
\hline Intercept & $\begin{array}{l}0.235 * * * \\
(5.71)\end{array}$ & $\begin{array}{l}0.127 * * \\
(2.43)\end{array}$ & $0.108 * * *$ \\
\hline COMOVE & $\begin{array}{l}6.055^{* * * *} \\
(4.90)\end{array}$ & $\begin{array}{l}4.527 * * * \\
(5.64)\end{array}$ & $1.528 * * *$ \\
\hline ANBETA & $\begin{array}{r}0.003 \\
(0.78)\end{array}$ & $\begin{array}{l}0.006^{*} \\
(1.78)\end{array}$ & $-0.003 *$ \\
\hline SAMEDATE & $\begin{array}{l}0.025^{* * *} \\
(3.44)\end{array}$ & $\begin{array}{r}0.000 \\
(0.02)\end{array}$ & $0.025 * * *$ \\
\hline$|R E T|$ & $\begin{array}{l}-0.012 * * * \\
(-8.99)\end{array}$ & $\begin{array}{l}-0.010 * * * \\
(-12.08)\end{array}$ & $-0.002 * * *$ \\
\hline |HISTRET| & $\begin{array}{l}-0.027 * * * \\
(-6.67)\end{array}$ & $\begin{array}{l}-0.026 * * * \\
(-7.28)\end{array}$ & -0.001 \\
\hline $\begin{array}{l}\text { Adj R-Squared } \\
\mathrm{N}\end{array}$ & $\begin{array}{l}0.119 \\
41,681\end{array}$ & $\begin{array}{l}0.080 \\
41,649\end{array}$ & \\
\hline
\end{tabular}

Panel A: Larger and Smaller Firms

\begin{tabular}{|c|c|c|c|}
\hline & Good News & Bad News & $\begin{array}{l}\text { Coefficient } \\
\text { Differences }\end{array}$ \\
\hline Intercept & $\begin{array}{l}-0.396 * * * \\
(-6.45)\end{array}$ & $\begin{array}{l}-0.224 * * * \\
(-3.18)\end{array}$ & $-0.172 * * *$ \\
\hline COMOVE & $\begin{array}{l}4.571 * * * \\
(6.03)\end{array}$ & $\begin{array}{l}6.022 * * * \\
(5.63)\end{array}$ & $-1.451 * * *$ \\
\hline ANBETA & $\begin{array}{r}0.002 \\
(0.77)\end{array}$ & $\begin{array}{l}0.011^{* * * *} \\
(2.92)\end{array}$ & $-0.009 * * *$ \\
\hline SAMEDATE & $\begin{array}{l}0.015^{* *} \\
(2.29)\end{array}$ & $\begin{array}{l}0.011 \\
(1.39)\end{array}$ & 0.004 \\
\hline$|R E T|$ & $\begin{array}{l}-0.011 \text { *** } \\
(-10.12)\end{array}$ & $\begin{array}{l}-0.012 * * * \\
(-11.82)\end{array}$ & 0.001 \\
\hline |HISTRET $\mid$ & $\begin{array}{l}-0.024 * * * \\
(-7.87)\end{array}$ & $\begin{array}{l}-0.031 * * * \\
(-7.53)\end{array}$ & $0.007 * * *$ \\
\hline$S I Z E$ & $\begin{array}{l}0.073 * * * \\
(16.28)\end{array}$ & $\begin{array}{l}0.061 * * * \\
(12.37)\end{array}$ & $0.012 * * *$ \\
\hline $\begin{array}{l}\text { Adj R-Squared } \\
\mathrm{N}\end{array}$ & $\begin{array}{l}0.176 \\
59,504\end{array}$ & $\begin{array}{c}0.182 \\
23,826\end{array}$ & \\
\hline
\end{tabular}

Panel B: Sign of Earnings News 
TABLE 4 (continued)

Non-Diversifiable Earnings Announcement Risk and Risk Premiums by Sample Partitions

$$
\begin{aligned}
\operatorname{ExVOL}_{q}= & \alpha_{0}+\alpha_{1} \operatorname{COMOVE}_{q}+\alpha_{2} \text { ANBETA }_{q}+\alpha_{3} \operatorname{SAMEDATE}_{q} \\
& +\alpha_{4}\left|\operatorname{RET}_{q}\right|+\alpha_{5}\left|\operatorname{HISTRET}_{q}\right|+\alpha_{6} \operatorname{SIZE}_{q}+\varepsilon_{q}
\end{aligned}
$$

\begin{tabular}{|c|c|c|c|}
\hline & Guidance & No Guidance & $\begin{array}{l}\text { Coefficient } \\
\text { Differences }\end{array}$ \\
\hline Intercept & $\begin{array}{l}-0.532 * * * \\
(-6.27)\end{array}$ & $\begin{array}{l}-0.274 * * * \\
(-4.57)\end{array}$ & $-0.258 * * *$ \\
\hline COMOVE & $\begin{array}{l}4.608 * * * \\
(4.56)\end{array}$ & $\begin{array}{l}5.094 * * * \\
(6.15)\end{array}$ & $-0.486^{*}$ \\
\hline ANBETA & $\begin{array}{l}0.003 \\
(0.65)\end{array}$ & $\begin{array}{l}0.005^{*} \\
(1.83)\end{array}$ & -0.002 \\
\hline SAMEDATE & $\begin{array}{l}0.021 * * \\
(2.39)\end{array}$ & $\begin{array}{c}0.011 \\
(1.58)\end{array}$ & $0.010^{* *}$ \\
\hline$|R E T|$ & $\begin{array}{l}-0.009 * * * \\
(-6.65)\end{array}$ & $\begin{array}{l}-0.012^{* * *} \\
(-13.09)\end{array}$ & $0.003 * * *$ \\
\hline |HISTRET $\mid$ & $\begin{array}{l}-0.021^{* * * *} \\
(-5.37)\end{array}$ & $\begin{array}{l}-0.028 * * * \\
(-8.54)\end{array}$ & $0.007 * *$ \\
\hline$S I Z E$ & $\begin{array}{l}0.083 * * * \\
(13.04)\end{array}$ & $\begin{array}{l}0.064 * * * \\
(15.48)\end{array}$ & $0.019 * * *$ \\
\hline $\begin{array}{l}\text { Adj R-Squared } \\
\mathrm{N}\end{array}$ & $\begin{array}{c}0.188 \\
26,429\end{array}$ & $\begin{array}{l}0.173 \\
56,901\end{array}$ & \\
\hline
\end{tabular}

Panel C: Management Earnings Guidance

\begin{tabular}{|c|c|c|c|}
\hline & After Close & Before Close & $\begin{array}{l}\text { Coefficient } \\
\text { Differences }\end{array}$ \\
\hline Intercept & $\begin{array}{l}-0.439 * * * \\
(-6.20)\end{array}$ & $\begin{array}{l}-0.294 * * * \\
(-4.33)\end{array}$ & $-0.145 * * *$ \\
\hline COMOVE & $\begin{array}{l}4.566^{* * * *} \\
(4.65)\end{array}$ & $\begin{array}{l}5.328^{* * * *} \\
(6.29)\end{array}$ & $-0.762 * *$ \\
\hline ANBETA & $\begin{array}{l}-0.001 \\
(-0.14)\end{array}$ & $\begin{array}{l}0.009^{* * * *} \\
(2.61)\end{array}$ & $-0.010 * * *$ \\
\hline SAMEDATE & $\begin{array}{c}0.004 \\
(0.44)\end{array}$ & $\begin{array}{l}0.024^{* * *} \\
(3.25)\end{array}$ & $-0.020 * * *$ \\
\hline$|R E T|$ & $\begin{array}{l}-0.010 * * * \\
(-8.94)\end{array}$ & $\begin{array}{l}-0.011 * * * \\
(-11.35)\end{array}$ & 0.001 \\
\hline $\mid$ HISTRET| & $\begin{array}{l}-0.021 * * * \\
(-5.73)\end{array}$ & $\begin{array}{l}-0.027^{* * * *} \\
(-7.48)\end{array}$ & $0.006 * * *$ \\
\hline$S I Z E$ & $\begin{array}{l}0.080 * * * \\
(14.02)\end{array}$ & $\begin{array}{l}0.060 * * * \\
(13.15)\end{array}$ & $0.020 * * *$ \\
\hline $\begin{array}{l}\text { Adj R-Squared } \\
\mathrm{N}\end{array}$ & $\begin{array}{l}0.153 \\
36,301\end{array}$ & $\begin{array}{c}0.165 \\
47,029\end{array}$ & \\
\hline
\end{tabular}

Panel D: Announcements Before and After Market Close 
TABLE 4 (continued)

Non-Diversifiable Earnings Announcement Risk and Risk Premiums by Sample Partitions

$$
\begin{aligned}
\text { ExVOL }_{q}= & \alpha_{0}+\alpha_{1} \text { COMOVE }_{q}+\alpha_{2} \text { ANBETA }_{q}+\alpha_{3} \text { SAMEDATE }_{q} \\
& +\alpha_{4}\left|\operatorname{RET}_{q}\right|+\alpha_{5}\left|\operatorname{HISTRET}_{q}\right|+\alpha_{6} \operatorname{SIZE}_{q}+\varepsilon_{q}
\end{aligned}
$$

\begin{tabular}{|c|c|c|c|}
\hline & Pre Crisis & Post Crisis & $\begin{array}{l}\text { Coefficient } \\
\text { Differences }\end{array}$ \\
\hline Intercept & $\begin{array}{l}-0.299^{* * * *} \\
(-4.08)\end{array}$ & $\begin{array}{l}-0.452^{* * *} \\
(-4.51)\end{array}$ & $0.153^{* * *}$ \\
\hline COMOVE & $\begin{array}{l}6.151^{* * *} \\
(7.00)\end{array}$ & $\begin{array}{l}3.757^{* * *} \\
(3.35)\end{array}$ & $2.394 * * *$ \\
\hline ANBETA & $\begin{array}{l}0.007^{* *} \\
(2.18)\end{array}$ & $\begin{array}{r}0.006 \\
(1.05)\end{array}$ & 0.001 \\
\hline SAMEDATE & $\begin{array}{l}0.014^{* *} \\
(2.01)\end{array}$ & $\begin{array}{l}0.021^{* *} \\
(2.15)\end{array}$ & $-0.070^{*}$ \\
\hline$|R E T|$ & $\begin{array}{l}-0.013 * * * \\
(-15.42)\end{array}$ & $\begin{array}{l}-0.009^{* * * *} \\
(-6.72)\end{array}$ & $-0.004 * * *$ \\
\hline $\mid$ HISTRET $\mid$ & $\begin{array}{l}-0.031^{* * *} \\
(-8.61)\end{array}$ & $\begin{array}{l}-0.020^{* * *} \\
(-4.31)\end{array}$ & $-0.011 * * *$ \\
\hline SIZE & $\begin{array}{l}0.066^{* * *} \\
(12.06)\end{array}$ & $\begin{array}{l}0.073^{* * *} \\
(12.65)\end{array}$ & $-0.007 * *$ \\
\hline $\begin{array}{l}\text { Adj R-Squared } \\
\mathrm{N}\end{array}$ & $\begin{array}{c}0.196 \\
51,005\end{array}$ & $\begin{array}{l}0.156 \\
32,325\end{array}$ & \\
\hline
\end{tabular}

Panel E: Announcements Pre and Post Financial Crisis

\begin{tabular}{|c|c|c|c|}
\hline & $\begin{array}{c}\text { High } \\
\text { SAMEDATE }\end{array}$ & $\begin{array}{c}\text { Low } \\
\text { SAMEDATE }\end{array}$ & $\begin{array}{l}\text { Coefficient } \\
\text { Differences }\end{array}$ \\
\hline Intercept & $\begin{array}{l}-0.320^{* * * *} \\
(-7.04)\end{array}$ & $\begin{array}{l}-0.227^{* * * *} \\
(-5.12)\end{array}$ & $-0.093^{* * *}$ \\
\hline COMOVE & $\begin{array}{l}5.167 * * * \\
(6.11)\end{array}$ & $\begin{array}{l}4.980^{* * *} \\
(5.72)\end{array}$ & 0.187 \\
\hline ANBETA & $\begin{array}{r}0.004 \\
(1.08)\end{array}$ & $\begin{array}{l}0.006^{*} \\
(1.79)\end{array}$ & -0.002 \\
\hline$|R E T|$ & $\begin{array}{l}-0.011^{* * *} \\
(-10.19)\end{array}$ & $\begin{array}{l}-0.011^{* * *} \\
(-11.86)\end{array}$ & 0.000 \\
\hline $\mid$ HISTRET $\mid$ & $\begin{array}{l}-0.026^{* * *} \\
(-7.90)\end{array}$ & $\begin{array}{l}-0.025^{* * *} \\
(-6.76)\end{array}$ & -0.0021 \\
\hline SIZE & $\begin{array}{l}0.077^{* * *} \\
(15.95)\end{array}$ & $\begin{array}{l}0.062^{* * *} \\
(13.56)\end{array}$ & $0.015^{* * *}$ \\
\hline $\begin{array}{l}\text { Adj R-Squared } \\
\text { N }\end{array}$ & $\begin{array}{r}0.192 \\
41,585\end{array}$ & $\begin{array}{l}0.161 \\
41,745\end{array}$ & \\
\hline
\end{tabular}

Panel F: Announcements with High and Low SAMEDATE 
Table 4 (continued)

Non-Diversifiable Earnings Announcement Risk and Risk Premiums by Sample Partitions

The table presents summary statistics for regressions of earnings announcement risk premiums, ExVOL, on measures of non-diversifiable earnings announcement risk. The sample of consists of 83,331 firm-quarters from 1996 to 2010. Good (Bad) News denotes whether actual earnings minus the pre-announcement consensus analyst forecast is positive (negative). No Guidance (Guidance) denotes whether the firm did not (did) provide pre-announcement guidance for quarter $q$. Larger (Smaller) Firms and denotes whether the firm's market value of equity, i.e., $S I Z E$, is above (below) the annual median. Before (After) Market Close denotes whether earnings were announced before (after) the market close. Pre (Post) Crisis denotes whether the earnings announcement was before (after) January 1, 2006. High (Low) SAMEDATE denotes whether the firm announced earnings on a day with above (below) the quarterly median of other firms announcing earnings, i.e., SAMEDATE. $t$-statistics based on standard errors clustered by firm and quarter are shown in parentheses. We do not include SIZE (SAMEDATE) in the tests based on subsamples partitioned by SIZE (SAMEDATE). See Appendix B for variable descriptions. $* * *, * *$, and $*$ denote significance at the $0.01,0.05$, and 0.10 levels, based on a two-sided test. 
TABLE 5

Non-diversifiable Earnings Announcement Risk and Risk Premiums by Expected Earnings Announcement Dates

\begin{tabular}{|c|c|c|c|c|}
\hline & All & Early & On-Time & Late \\
\hline Intercept & $\begin{array}{l}-0.324 * * * \\
(-5.08)\end{array}$ & $\begin{array}{l}-0.282^{* * *} \\
(-3.39)\end{array}$ & $\begin{array}{l}-0.273^{* * *} \\
(-3.97)\end{array}$ & $\begin{array}{l}-0.288^{* * * *} \\
(-4.14)\end{array}$ \\
\hline COMOVE & $\begin{array}{l}4.850 * * * \\
(5.35)\end{array}$ & $\begin{array}{l}4.536 * * * \\
(3.02)\end{array}$ & $\begin{array}{l}5.637 * * * \\
(4.94)\end{array}$ & $\begin{array}{l}5.364 * * * \\
(4.51)\end{array}$ \\
\hline ANBETA & $\begin{array}{c}0.05 \\
(1.58)\end{array}$ & $\begin{array}{l}-0.001 \\
(-0.28)\end{array}$ & $\begin{array}{l}0.008^{* *} \\
(2.03)\end{array}$ & $\begin{array}{r}0.003 \\
(0.60)\end{array}$ \\
\hline SAMEDATE & $\begin{array}{l}0.015^{* *} \\
(2.24)\end{array}$ & $\begin{array}{l}0.017 * \\
(1.73)\end{array}$ & $\begin{array}{r}0.011 \\
(1.38)\end{array}$ & $\begin{array}{l}0.018^{* *} \\
(2.17)\end{array}$ \\
\hline$|R E T|$ & $\begin{array}{l}-0.010 * * * \\
(-10.92)\end{array}$ & $\begin{array}{l}-0.009^{* * *} \\
(-7.94)\end{array}$ & $\begin{array}{l}-0.011 * * * \\
(-8.97)\end{array}$ & $\begin{array}{l}-0.011^{* * * *} \\
(-8.93)\end{array}$ \\
\hline $\mid$ HISTRET $\mid$ & $\begin{array}{l}-0.029 * * * \\
(-7.29)\end{array}$ & $\begin{array}{l}-0.024 * * * \\
(-3.93)\end{array}$ & $\begin{array}{l}-0.026^{* * *} \\
(-5.11)\end{array}$ & $\begin{array}{l}-0.028 * * * \\
(-5.93)\end{array}$ \\
\hline$S I Z E$ & $\begin{array}{l}0.067 * * * \\
(15.40)\end{array}$ & $\begin{array}{l}0.056 * * * \\
(9.72)\end{array}$ & $\begin{array}{l}0.063^{* * * *} \\
(14.02)\end{array}$ & $\begin{array}{l}0.062 * * * \\
(11.46)\end{array}$ \\
\hline $\begin{array}{l}\text { Adj R-Squared } \\
\mathrm{N}\end{array}$ & $\begin{array}{c}0.180 \\
79,548\end{array}$ & $\begin{array}{l}0.160 \\
16,369\end{array}$ & $\begin{array}{l}0.182 \\
27,821\end{array}$ & $\begin{array}{l}0.163 \\
20,992\end{array}$ \\
\hline
\end{tabular}

The table presents summary statistics for regressions of earnings announcement risk premiums, ExVOL, on measures of non-diversifiable earnings announcement risk. The sample of consists of 83,331 firm-quarters from 1996 to 2010. Early, On-time, and Late denote whether the firm announced earnings before, within one day of, or after the expected earnings announcement date estimated as in Cohen et al. (2007). $t$-statistics based on standard errors clustered by firm and quarter are shown in parentheses. See Appendix B for variable descriptions. ***, **, and * denote significance at the $0.01,0.05$, and 0.10 levels, based on a two-sided test. 
TABLE 6

Alternative Proxies for Non-Diversifiable Volatility Risk

$$
\operatorname{ExVOL}_{q}=\alpha_{0}+\alpha_{1} X X X_{q}+\alpha_{2} \text { ANBETA }_{q}+\alpha_{3} S A M E D A T E_{q}+\varepsilon_{q}
$$

Panel A: Alternative Proxies for Volatility Risk

\begin{tabular}{lccccc} 
& Pred. Sign & $(1)$ & $(2)$ & $(3)$ & $(4)$ \\
\cline { 2 - 6 } Intercept & $(?)$ & 0.015 & $-0.069^{*}$ & $0.047 * * *$ & -0.025 \\
VIXCOMOVE & $(+)$ & $1.036^{* * *}$ & $(-1.82)$ & $(4.76)$ & $(-0.64)$ \\
VOLBETA & & $(6.46)$ & $(6.33)$ & & \\
& $(+)$ & & & $0.029 * * *$ & $0.032^{* * *}$ \\
ANBETA & $(+)$ & & -0.002 & $(8.24)$ & $(8.29)$ \\
& & & $(-0.47)$ & $-0.014^{* * *}$ \\
SAMEDATE & $(+)$ & & $0.016^{* *}$ & & $(-3.63)$ \\
Adj R-Squared & & & $(2.30)$ & & $0.015^{* *}$ \\
& & 0.005 & 0.006 & 0.012 & 0.014
\end{tabular}

Panel B: Non-Return-based Proxies for Volatility Risk

\begin{tabular}{|c|c|c|c|c|c|}
\hline & Pred. Sign & (1) & $(2)$ & (3) & (4) \\
\hline Intercept & (?) & $\begin{array}{l}-0.059 * * * \\
(-5.26)\end{array}$ & $\begin{array}{l}-0.157 * * * \\
(-3.95)\end{array}$ & $\begin{array}{l}-0.016 \\
(-1.39)\end{array}$ & $\begin{array}{l}-0.134 * * * \\
(-3.26)\end{array}$ \\
\hline SP500 & $(+)$ & $\begin{array}{l}0.256^{* * * *} \\
(18.24)\end{array}$ & $\begin{array}{l}0.257 * * * \\
(18.36)\end{array}$ & & \\
\hline BELLWETHER & $(+)$ & & & $\begin{array}{l}0.043 * * * \\
(3.50)\end{array}$ & $\begin{array}{l}0.045 * * * \\
(3.69)\end{array}$ \\
\hline$A N B E T A$ & $(+)$ & & $\begin{array}{l}-0.003 \\
(-0.86)\end{array}$ & & $\begin{array}{l}-0.000 \\
(-0.06)\end{array}$ \\
\hline$S A M E D A T E$ & $(+)$ & & $\begin{array}{l}0.019^{* * * *} \\
(2.68)\end{array}$ & & $\begin{array}{l}0.022 * * * \\
(3.01)\end{array}$ \\
\hline Adj R-Squared & & 0.052 & 0.053 & 0.001 & 0.002 \\
\hline
\end{tabular}

The table presents the summary statistics for regressions of earnings announcement risk premiums, ExVOL, on measures of alternative proxies for non-diversifiable earnings announcement volatility risk, $X X X$, i.e., VIXCOMOVE, VOLBETA, SP500, and BELLWETHER. The sample of consists of 83,331 firm-quarters from 1996 to 2010. $t$-statistics based on standard errors clustered by firm and quarter are shown in parentheses. See Appendix B for variable descriptions. $* * *, * *$, and $*$ denote significance at the $0.01,0.05$, and 0.10 levels, based on a two-sided test. 
TABLE 7

Straddle Returns by COMOVE Quintiles

Panel A: Mean Straddle Returns by COMOVE Quintile

\begin{tabular}{ccccccc} 
& $1(\mathrm{Low})$ & 2 & 3 & 4 & $5(\mathrm{High})$ & High-Low \\
\cline { 2 - 6 } Mean & 0.020 & 0.019 & 0.007 & -0.003 & -0.020 & -0.040 \\
$t$-statistic & $(3.30)$ & $(2.13)$ & $(1.02)$ & $(-0.49)$ & $(-2.94)$ & $(-5.09)$
\end{tabular}

Panel B: Regression Results of Straddle Returns

\begin{tabular}{lclllc} 
& Pred. Sign & \multicolumn{1}{c}{$(1)$} & $(2)$ & $(3)$ & $(4)$ \\
\cline { 2 - 6 } Intercept & $(?)$ & $-0.012 * *$ & $-0.013 * *$ & $-0.093 * * *$ & $-0.094 * * *$ \\
COMOVE & & $(-2.04)$ & $(-2.13)$ & $(-4.74)$ & $(-4.79)$ \\
& $(-)$ & $-0.875 * * *$ & $-0.928 * * *$ & $-0.895 * * *$ & $-0.952 * * *$ \\
ANBETA & $(-)$ & $(-3.95)$ & $(-4.13)$ & $(-4.11)$ & $(-4.31)$ \\
& & & $-0.003 *$ & & $-0.003 *$ \\
SAMEDATE & $(-)$ & & $(-1.74)$ & & $(-1.89)$ \\
& & & & $0.015 * * *$ & $0.015 * * *$ \\
Adj R-Squared & & 0.002 & 0.000 & $(3.93)$ & $(3.96)$ \\
N & & 39,688 & 39,688 & 39,688 & 39,688
\end{tabular}

Panel C: Regression Results of Abnormal Straddle Returns

\begin{tabular}{lccccc} 
& Pred. Sign & $(1)$ & $(2)$ & $(3)$ & $(4)$ \\
\cline { 2 - 6 } Intercept & $(?)$ & $0.035^{* * *}$ & $0.034^{* * *}$ & 0.009 & 0.007 \\
& & $(4.08)$ & $(3.96)$ & $(0.27)$ & $(0.21)$ \\
COMOVE & $(-)$ & $-2.376^{* * *}$ & $-2.578^{* * *}$ & $-2.381 * * *$ & $-2.585^{* * *}$ \\
& & $(-5.33)$ & $(-5.76)$ & $(-5.35)$ & $(-5.79)$ \\
ANBETA & $(-)$ & & $-0.009 * * *$ & & $-0.009 * * *$ \\
& & & $(-2.60)$ & & $(-2.63)$ \\
SAMEDATE & $(-)$ & & & 0.005 & 0.005 \\
& & & & $(0.75)$ & $(0.78)$ \\
Adj R-Squared & & 0.002 & 0.000 & 0.000 & 0.003 \\
N & & 24,762 & 24,762 & 24,762 & 24,762
\end{tabular}

Panel A presents time-series means of announcement-window straddle returns for quintiles of non-diversifiable earnings announcement volatility risk, COMOVE. Straddle returns equal the returns from holding a delta-neutral straddle position comprised of at-the-money call and put options of equal time-to-expiration from the $t-1$ to $t+1$, where $t$ is the earnings announcement date. $t$-statistics are based on the time-series distribution. Panel B contains the summary statistics for regressions of announcement-window straddle returns on proxies for non-diversifiable earnings announcement risk. Panel $\mathrm{C}$ presents analogous results after subtracting straddle returns for the same firms during a randomly drawn pseudo-announcement date. $t$-statistics based on standard errors clustered by firm and quarter are shown in parentheses in panels B and C. See Appendix B for variable descriptions. 